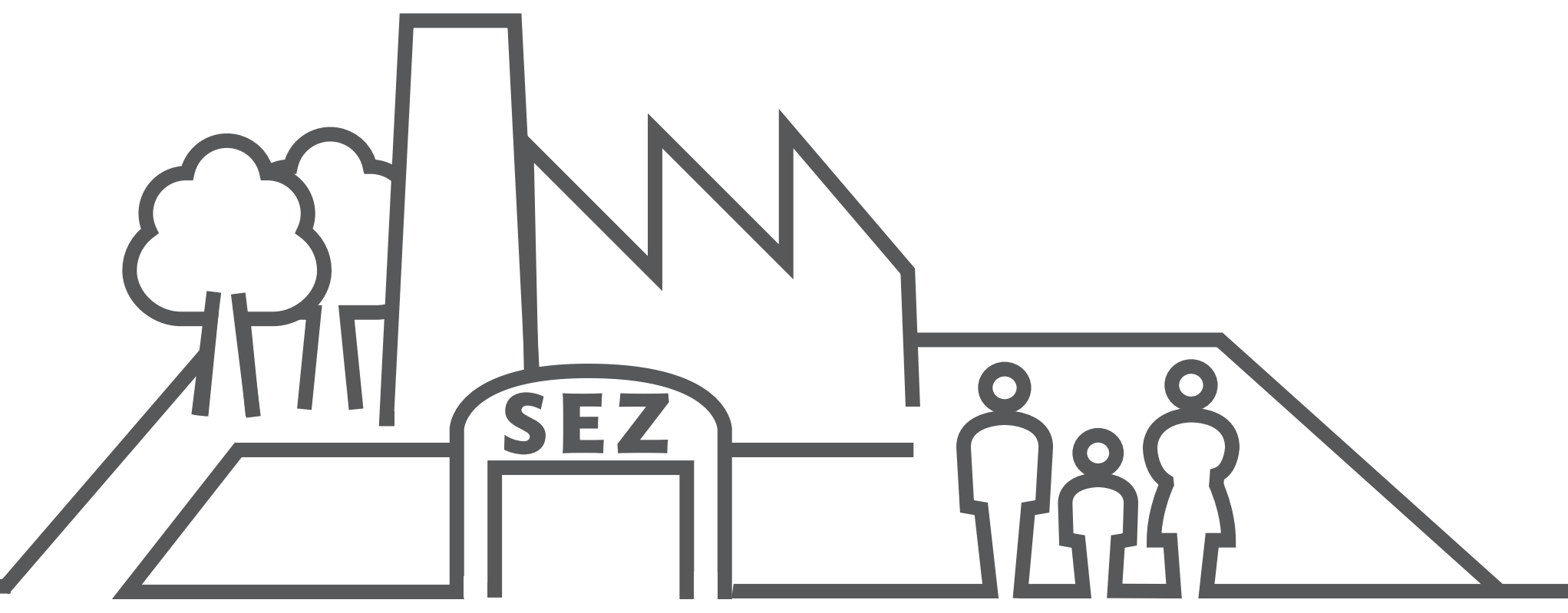

A HEALTH IMPACT ASSESSMENT FRAMEWORK FOR SPECIAL ECONOMIC ZONES IN THE GREATER MEKONG SUBREGION

MAY 2018 



\section{A HEALTH IMPACT ASSESSMENT FRAMEWORK FOR SPECIAL ECONOMIC ZONES IN THE GREATER MEKONG SUBREGION}

MAY 2018 
(C) 2018 Asian Development Bank

6 ADB Avenue, Mandaluyong City, 1550 Metro Manila, Philippines

Tel +63 2632 4444; Fax +6326362444

www.adb.org

Some rights reserved. Published in 2018.

ISBN 978-92-9261-144-6 (print), 978-92-9261-145-3 (electronic)

Publication Stock No. TCS189221-2

DOI: http://dx.doi.org/10.22617/TCS189221-2

The views expressed in this publication are those of the authors and do not necessarily reflect the views and policies of the Asian Development Bank (ADB) or its Board of Governors or the governments they represent.

ADB does not guarantee the accuracy of the data included in this publication and accepts no responsibility for any consequence of their use. The mention of specific companies or products of manufacturers does not imply that they are endorsed or recommended by $\mathrm{ADB}$ in preference to others of a similar nature that are not mentioned.

By making any designation of or reference to a particular territory or geographic area, or by using the term "country" in this document, ADB does not intend to make any judgments as to the legal or other status of any territory or area.

This work is available under the Creative Commons Attribution 3.0 IGO license (CC BY 3.0 IGO) https://creativecommons.org/licenses/by/3.0/igo/. By using the content of this publication, you agree to be bound by the terms of this license. For attribution, translations, adaptations, and permissions, please read the provisions and terms of use at https://www.adb.org/terms-use\#openaccess.

This CC license does not apply to non-ADB copyright materials in this publication. If the material is attributed to another source, please contact the copyright owner or publisher of that source for permission to reproduce it. ADB cannot be held liable for any claims that arise as a result of your use of the material.

Please contact pubsmarketing@adb.org if you have questions or comments with respect to content, or if you wish to obtain copyright permission for your intended use that does not fall within these terms, or for permission to use the ADB logo.

Notes:

In this publication, “\$” refers to United States dollars.

ADB recognizes "Laos" as "the Lao People’s Democratic Republic," and "Vietnam" as "Viet Nam."

Corrigenda to ADB publications may be found at http://www.adb.org/publications/corrigenda. 


\section{Contents}

Tables and Figures $\quad$ iv

Acknowledgments $\quad$ v

Abbreviations vi vi vals

Executive Summary vii

1 Introduction 1

1.1 Special Economic Zones in the Greater Mekong Subregion 1

1.2 Health Impact Assessment in the Greater Mekong Subregion 3

2 Country Policy, Legal, and Administrative Frameworks 5

2.1 Cambodia 5

2.2 Lao People's Democratic Republic $\quad 7$

2.3 Myanmar 8

2.4 Thailand 9

2.5 Viet Nam 13

3 Health Opportunities and Risks Associated with Special Economic Zones $\quad 16$

4 A Health Impact Assessment Framework for Special Economic Zones 18

$\begin{array}{ll}4.1 \text { Inputs } & 19\end{array}$

4.2 Processes 20

4.3 Outputs 22

4.4 Outcomes 22

4.5 Impacts $\quad 22$

5 Health Impact Assessment Guidelines for Special Economic Zones 23

5.1 Scoping Phase 24

5.2 Baseline Data Collection $\quad 26$

5.3 Risk Assessment 27

5.4 Development and Implementation of Management Measures 27

$\begin{array}{ll}5.5 \text { Surveillance and Response } & 28\end{array}$

5.6 Transboundary and Cross-Border Surveillance and Response 30

Appendixes

$1 \quad$ Indicator Suite for Baseline Data and Surveillance 31

2 Additional Data Collection Tools $\quad 35$

3 Grievance Management Resources 39

Gender Equality Standards for Special Economic Zone Authorities
and Businesses

$5 \quad$ Health Risk Assessment Tools 41 


\section{Tables and Figures}

Tables

1 Scoping Phase: Investigation into the Special Economic Zone Context 24

2 Scoping Phase: Preexisting Data Availability and Quality Tool 26

3 Differences between Leading and Lagging Health Indicators 27

Figures

1 Special Economic Zones, Industrial Zones, and Economic Corridors

within the Greater Mekong Subregion 2

2 Health Opportunities and Risks Associated with Special Economic Zone

$\begin{array}{ll}\text { Development } & 17\end{array}$

3 Health Impact Assessment Framework for Special Economic Zone Development 19

4 Health Impact Assessment Process for Special Economic Zone Development 21

5 Resources (Financial and Human) Required for Health Impact Assessment

Work Associated with Special Economic Zones and Border Communities 23

6 International Requirements for the Managem ent of Social and Environmental Risks and Impacts

7 Different Surveillance Data Required for Effective Management of Community and Worker Health and Safety Risks and Issues 


\section{Acknowledgments}

The development of the Health Impact Assessment Framework for Special Economic Zones in the GMS was led by the consultants Janis Shandro, Gene Peralta, and the ADB team leader Susann Roth. A team of national consultants including Liza Tabora, Oulavanh Sinsamphanh, Chintana Souvanachack, Sobonn Ros, and Shree Acharya supported the national discussions and input. The document was developed in close consultation with GMS countries, SEZ managers and the private sector. A regional consultation workshop was held in November in Bangkok and led to the endorsement of the framework by government stakeholders. The ADB Southeast Asia Regional Cooperation team also provided valuable input and ensured relevance of this framework for the ADB context. We thank all contributors for making this document practical and useful. 


\section{Abbreviations}

$\begin{array}{ll}\text { ADB } & \text { Asian Development Bank } \\ \text { ASEAN } & \text { Association of Southeast Asian Nations } \\ \text { BOI } & \text { Board of Investment (Thailand) } \\ \text { CDC } & \text { Council for the Development of Cambodia } \\ \text { CSEZB } & \text { Cambodian Special Economic Zone Board } \\ \text { EIA } & \text { Environmental Impact Assessment } \\ \text { GMS } & \text { Greater Mekong Subregion } \\ \text { HIA } & \text { Health Impact Assessment } \\ \text { km } & \text { square kilometer } \\ \text { MOU } & \text { memorandum of understanding } \\ \text { PCSEZ } & \text { Policy Committee for Special Economic Zones (Thailand) } \\ \text { SEZ } & \text { special economic zone } \\ \text { SEZ TSC } & \text { Special Economic Zones Trouble Shooting Committee (Cambodia) } \\ \text { VIHEMA } & \text { Vietnam Health Environment Management Agency }\end{array}$




\section{Executive Summary}

Introduction: Across the Greater Mekong Subregion (GMS), there are over 500 special economic zones (SEZs) and industrial zones. Many have been strategically located along or near the GMS economic corridors. The estimated population associated with SEZ development and border areas of economic corridors is over 50 million people. The proposed health impact assessment (HIA) framework for SEZs in the GMS recognizes these areas as the economic engines of the subregion and aims to maximize benefits for all. Its aim is to provide enhanced guidance for identifying, mitigating and managing health risks and impacts related to this unprecedented industrial and economic development happening in and around SEZs. It seeks to address transboundary health issues associated with mobile and migrant worker populations. The framework does not seek to inform a decision on whether SEZ development should or should not occur. Rather, it proposes HIA as an effective SEZ management support tool to achieve optimum benefits for businesses and associated communities alike.

Special economic zone and health impact assessment policies across the Greater Mekong Subregion: Across the GMS, each country differs as to how SEZs are organized and managed. They also differ in how health is addressed in impact assessments. Despite the differences, all GMS countries have prioritized support for SEZ development and for HIA capacity building. This opens the door for HIA as a tool for better SEZs.

Health opportunities and risks associated with special economic zones: SEZs tend to be located outside of capital regions. As such, infrastructure (e.g., roads and hospitals), services (testing and treatment) and knowledge, and attitudes and practices around health and determinants of health (e.g., waste management) are generally less developed than in urban settings. Also, as SEZs are strategically placed to take advantage of economic corridors, crossborder collaboration and, consequently, transient migrant populations are to be expected. The very nature of business within an SEZ varies, both by industry type and by nationality. SEZs are and will be culturally diverse locations. Taking all this into consideration, they can hold unique risks to local communities and workers if left unidentified and unmanaged. These conditions also provide opportunities for communities to take advantage of better living and working conditions and improved access to health services.

A health impact assessment framework for special economic zones in the Greater Mekong Subregion: The HIA framework is focused on regions, communities, and areas supporting SEZ development rather than individual SEZs or SEZ businesses. The framework places people directly affected by or associated with SEZ development at the center, as they interface with the SEZ as well as its associated facilities and activities. SEZ-affected people could be considered those who have been resettled as a result of SEZ development; have their livelihoods positively impacted due to zone development (economic opportunities); have their livelihoods negatively impacted due to zone development (economic displacement); live adjacent to a zone; live adjacent to worker accommodation facilities for the SEZ; live along 
economic and transportation corridors associated with SEZ-related industrial traffic; work in the construction of the zone and associated businesses, or; work in the established SEZ businesses.

The framework highlights that political support, collaboration, and commitments from a number of government authorities are required for successful implementation and optimization of HIA as a management tool for SEZs. People within these institutions are essential for maximizing health opportunities while identifying and managing health risks for current and future SEZ development. These contributions will result in a number of actions that will see improved access to appropriate health services for workers and community members and a reduction of identified health risks through the initiation of mitigation and management measures. There will be enhanced space for focus on health promotion, and the establishment of a surveillance and response system will allow for accurate and timely data on priority and emerging health risks.

Health impact assessment guidelines for special economic zones: To support the GMS HIA framework for SEZs, HIA guidelines have been developed. An HIA will be considered in three scenarios. It is proposed that a retrospective HIA for preexisting SEZs will be conducted in order to address any current health risks and impacts and to ensure expansion plans for further development incorporate effective mitigation and health promotion actions. A prospective HIA for newly proposed SEZs or SEZs yet to undergo significant development will be conducted to ensure the zone is developed in a strategic manner that incorporates, plans for, and manages health risks, impacts, and opportunities right from the beginning. A high-level scoping phase of an HIA for border communities along economic corridors will be conducted to allow for the identification of any potential, current, or emerging health risks as these regions face a higher likelihood for future SEZ development. Given the nature of SEZs will change over time, an HIA will be accomplished to allow for the rapid identification of critical issues requiring management. The HIA process needs to be responsive and continual as this type of development is dynamic; the zone will continue to change and grow. New businesses will emerge, and population demographics will change over time. As such, it can be anticipated that health risks will also change.

The HIA process will be accomplished by a multisector HIA team (with representation from the health ministry, SEZ authority, and environment ministry, with participation from other agencies). Initial phases will identify key issues requiring attention, the availability and quality of data associated with these issues, and set a work plan for further data collection. Data may be required to understand the contextual drivers that hold influence on current health issues of concern and should strategically identify areas that can be strengthened to have a positive influence on health outcomes (which may also represent a data requirement).

Next phases are focused on risk assessment and development and implementation of mitigation and management measures which will focus on prioritizing issues and resources to address risks requiring attention. The management of health risks in SEZ regions and economic corridors requires a systematic and collaborative approach. Health protection and promotion measures should be both based upon evidence and prioritized as per risk assessment findings. This phase will be accomplished in collaboration between the HIA team and officials from other relevant agencies, on the one hand, and the private sector, on the other, to ensure all are aware of present or potential health risks and can participate in appropriate management measures where appropriate. 
The final phase involves the development and implementation of a surveillance and response system. Expanded GMS-wide surveillance with a focus on border provinces associated with SEZs and economic corridors is recommended given developing crossborder zones. Surveillance of these areas is crucial not only from a trade, investment, and economic opportunity perspective, but also to protect and enhance the health and well-being of populations on both sides of the border. 



\section{Introduction}

Across the Greater Mekong Subregion (GMS), ${ }^{1}$ there are over 500 special economic zones (SEZs) and industrial zones. Many of these zones have been strategically located along or near the established GMS economic corridors (Figure 1). The estimated population associated with SEZ development and border areas of economic corridors is over 50 million people.

The overarching objective of this health impact assessment (HIA) framework for SEZs in the GMS is to provide enhanced guidance for identifying, mitigating, and managing health risks and impacts related to unprecedented industrial and economic development. This framework supports and promotes in-country HIA processes and seeks to address transboundary health issues associated with mobile and migrant worker populations in SEZs and economic corridors. In doing so, it recognizes SEZs and economic corridors as the economic engines of the subregion and aims to maximize the benefits for all.

\subsection{Special Economic Zones in the Greater Mekong Subregion}

The development of SEZs and economic corridors has been a priority for GMS countries as they look toward a long-term vision of growth, prosperity, and acceleration of regional development. The focus is on enhancing economic opportunities, trade, infrastructure, and business development, while improving regional linkages to major markets within and beyond the GMS. ${ }^{2}$ An overarching goal of SEZ development is to optimize development opportunities and benefits for regions outside of capital centers such as Ha Noi, Viet Nam; and Bangkok, Thailand. ${ }^{3}$

While the term SEZ is often used interchangeably with free trade zones, export processing zones, industrial zones, economic and technology development zones, high-tech zones, science and innovation parks, free ports, enterprise zones, and others, there are unique features of SEZs compared to other economic zones. In fact, SEZs can vary quite considerably across the GMS, especially in terms of organization and management.

For instance, SEZs can represent geographically defined areas containing a number of businesses within a physically secured and gated area, separate from the general population

1 The GMS comprises six countries linked by the Mekong River: Cambodia, the People's Republic of China, Myanmar, the Lao People's Democratic Republic, Thailand, and Viet Nam.

2 Asian Development Bank. 2016. Review of Configuration of the Greater Mekong Subregion Economic Corridors. Manila. https://www.adb.org/sites/default/files/institutional-document/214361/configuration-gms-corridors. pdf.

3 Asian Development Bank. 2016. The Role of Special Economic Zones in Improving Effectiveness of GMS Economic Corridors. Manila. https://www.adb.org/sites/default/files/institutional-document/214316/role-sez-gms.pdf (retrieved on 18 March 2017). 
A Health Impact Assessment Framework for Special Economic Zones in the Greater Mekong Subregion

Figure 1. Special Economic Zones, Industrial Zones, and Economic Corridors within the Greater Mekong Subregion

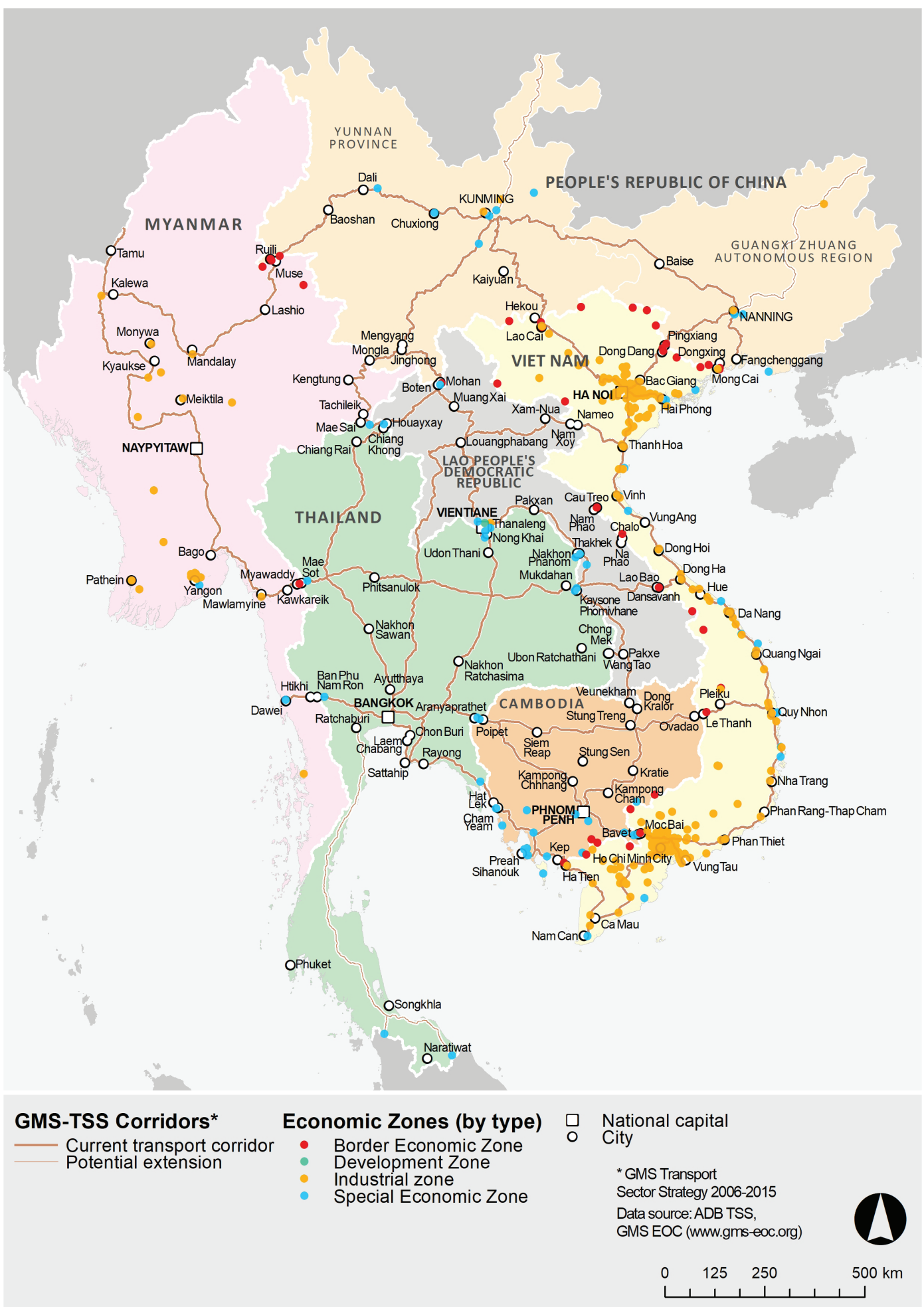

Source: Asian Development Bank. 2018. Review of Configuration of the Greater Mekong Subregion Economic Corridors. Manila. DOI: http://dx.doi.org/10.22617/TCS179180. 
(such as Phnom Penh SEZ, Cambodia). SEZs can also represent entire districts whereby individual projects will vary in terms of type and the presence of buffer zones (such as Nghi Son SEZ, Viet Nam). SEZs can also represent a combination of the two aforementioned arrangements (such as the Savan-Seno SEZ, in the Lao People's Democratic Republic).

In terms of management, SEZs can also vary. In some cases, SEZs are owned, operated, and managed entirely by a private investor (or investor group). In other cases, projects within the SEZ can be individually owned and operated by private investors; however, the management of the zone itself is the responsibility of a government agency (normally an SEZ authority). It is also possible for the zone to be owned, operated, and managed by a joint venture between government authorities and the private sector.

Regardless of the organizational and management attributes of SEZs, they all offer benefits for investors. SEZs tend to have separate customs areas (duty-free benefits) and streamlined procedures for business start-ups (to reduce the "red tape"). Businesses within SEZs can have the opportunity to operate under more relaxed laws. ${ }^{4}$

\subsection{Health Impact Assessment in the Greater Mekong Subregion}

An HIA is a systematic approach to assessing the health impacts and risks (both positive and negative) associated with an event, project, or policy that uses qualitative, quantitative, and participatory methods. ${ }^{5}$ An HIA accomplished to international standards assesses environmental, social, and culturally appropriate determinants of health; provides recommendations for subsequent management of health risks and impacts; and outlines appropriate surveillance and response mechanisms. ${ }^{6}$ HIAs are strongly supported by a variety of industry associations and sectors. ${ }^{7}$

The HIA, like SEZ development, has become a priority for GMS countries. The Lao People's Democratic Republic (Lao PDR), Thailand, and Viet Nam have embedded HIA policies within their legislation. ${ }^{8}$ Cambodia and Myanmar have initiatives focused on strengthening health components within the environmental impact assessment (EIA) process. The Asian Development Bank (ADB) has been supporting these countries to provide HIA tools and

4 Foreign Investment Advisory Service. 2008. Special Economic Zones: Performance, Lessons Learned, and Implications for Zone Development. Washington, DC: World Bank.

5 World Health Organization. 2015. Health Impact Assessment. http://www.who.int/hia/en/ (retrieved on 16 November 2017).

6 International Finance Corporation. 2009. Introduction to Health Impact Assessment. Washington, DC. http:// www.ifc.org/wps/wcm/connect/a0f1120048855a5a85dcd76a6515bb18/HealthImpact.pdf?MOD=AJPERES (retrieved on 10 July 2017); Asian Development Bank. 1992. Guidelines for the Health Impact Assessment of Development Projects. https://www.adb.org/documents/guidelines-health-impact-assessment-developmentprojects (retrieved on 10 July 2017).

7 International Petroleum Industry Environmental Conservation Association. 2016. Health Impact Assessment: A Guide for the Oil and Gas Industry. http://www.ipieca.org/news/ipieca-iogp-launches-the-revised-healthimpact-assessment-guide/ (retrieved on 10 July 2017); International Council on Mining and Minerals (ICMM). 2010. Good Practice Guidance on Health Impact Assessment. London, UK. https://www.icmm.com/website/ publications/pdfs/health-and-safety/792.pdf (retrieved on 10 July 2017).

8 World Health Organization. 2013. Biregional Meeting on Healthy Borders in the Greater Mekong Subregion, Session 4. http://www.searo.who.int/thailand/news/Session_4_health_impact_assessments.pdf (retrieved on 10 July 2017). 
guidance; enhance HIA capacity building; support new and existing partnerships and networks for HIA; and undertake HIA demonstration projects. ${ }^{9}$ This current HIA framework for SEZ development is part of ADB's HIA support for GMS countries. The framework does not seek to inform a decision on whether SEZ development should or should not occur. Rather, it should be viewed as an SEZ management support tool with the aim of achieving optimum benefits for businesses and associated communities alike. Also, while the framework has been developed for SEZs, the HIA approach is relevant for all industrial estates or zone settings.

9 Asian Development Bank. 2016. HIA Greater Mekong Subregion Health Impact Assessment Project. Manila. https://www.adb.org/sites/default/files/publication/186064/gms-hia-project.pdf (retrieved on 10 July 2017). 


\section{Country Policy, Legal, and Administrative Frameworks}

This section provides an outline of GMS country-specific policy, legal, and administrative frameworks associated with both SEZ development and HIA.

\subsection{Cambodia}

\subsubsection{Special Economic Zone Development in Cambodia}

On 29 December 2005, the Government of Cambodia established a subdecree outlining the legal framework for SEZ development (footnote 3). Article 2 of the subdecree defines SEZs as: ${ }^{10}$

Special area[s] for the development of the economic sectors which brings together all industrial and other related activities and may include General Industrial Zones and/or Export Processing Zones. Each Special Economic Zone shall have a production area which may have a free trade area, service area, residential area and tourist area.

SEZs were established to initiate economic linkages to rural areas, diversify and expand industries operating in-country, and promote industrial development outside the nation's capital, Phnom Penh. ${ }^{11}$ SEZs in Cambodia are almost all owned and managed by foreign, private investors. To be eligible to own and operate an SEZ, the developer must have a minimum of 50 hectares (124 acres) of land; the construction of a perimeter fence and the provision of the necessary infrastructure (including roads, electricity and water supply to service SEZ businesses) is required. ${ }^{12}$

SEZs in Cambodia are intended to serve as "enclaves that provide a stable business environment, reasonable infrastructure and public utilities, and less red tape" (footnote 3). SEZ owners and businesses located in SEZs are provided a "one-stop" service, with all relevant government ministries accessible and present on an SEZ site. This serves to process relevant documentation that owners and businesses require to be able to export and import goods, employ workers, and accomplish other regulatory matters (footnote 12). SEZ owners and businesses are guaranteed no price or foreign exchange controls, a $20 \%$ corporate tax rate, free remittance of foreign currency, exemption from import duty and value-added tax, and tax holidays (footnote 3).

10 The decree is formally referred to as "Sub-Decree No. 147 on the Organization and Functioning of the CDC". See Council for the Development of Cambodia. 2017. The Special Economic Zones. http://www.cambodiainvestment. gov.kh/investment-scheme/the-special-economic-zones.html (retrieved on 1 November 2017).

11 World Bank. 2012. Cambodia Enterprise Survey 2012. Washington, DC.

12 P. Warr and J. Menon. 2015. Cambodia's Special Economic Zones. ADB Economics Working Paper Series. No. 459. Manila: Asian Development Bank. 
The Cambodian Special Economic Zone Board (CSEZB), a subsidiary of the Council for the Development of Cambodia (CDC), governs SEZ development. The CDC is also responsible for the Special Economic Zones Trouble Shooting Committee (SEZ TSC), which serves to reconcile technical or legal issues associated with SEZ development and to receive grievances from zone developers and zone investors. According to Article 4.1 of the SEZ subdecree, the following officials form the SEZ TSC: ${ }^{13}$

- Chairman of the CDC;

- Minister of the Council of Ministers;

- Minister of Economy of Finance;

- Minister of Commerce;

- Minister of Land Management, Urbanism and Construction;

- Minister of Environment;

- Minister of Industry, Mines and Energy;

- Minister of Public Works and Transportation;

- Minister of Labor and Vocational Training;

- Secretary General of the CDC; and

- Secretary General of the CSEZB.

SEZs in Cambodia are primarily export processing facilities, meaning SEZ businesses will sell the majority of their outputs to foreign markets. SEZs located in close proximity to Sihanoukville Port or the Southern Corridor (between Phnom Penh and Vung Tau deepsea port) are reportedly preferred by investors when compared to land-based regions (i.e., Poipet and Koh Kong SEZs) due to ease of export. Based on available information, there are 17 SEZs operating in Cambodia and an additional 30 authorized to begin construction. ${ }^{14}$ The operational SEZs are

1. Phnom Penh SEZ in Angk Snuol District, Kandal Province

2. Sihanoukville SEZ in Prey Nop District, Sihanoukville Province

3. Poi Pet O'Neang SEZ in O'Chhrav District, Banteay Meanchey Province

4. Sihanoukville SEZ in Stueng Hav District, Sihanoukville Province

5. Manhattan (Svay Rieng) SEZ in Bavet City, Svay Rieng Province

6. Kampot SEZ in the Kampot district, Kampot Province

7. Tai Seng Bavet SEZ in Bavet District, Svay Rieng Province

8. Neang Kok Koh Kong SEZ in Mundul Seyma District, Koh Kong Province

9. Dragon King SEZ in Bavet City, Svay Rieng Province

10. H.K.T. SEZ in Prey Nub District, Sihanoukville Province

11. Shandong Sunshell Svay Rieng SEZ in Bavet City, Svay Rieng Province

12. Sanco Poi Pet SEZ in Poi Pet City, Banteay Meanchey Province

13. Suvannaphum SEZ in Kean Svay District, Kandal Province

14. Sihanoukville Port SEZ in Sihanoukville City, Sihanoukville Province

15. High-Park SEZ in Svay Rieng, Province

16. Qi Lu Jian Pu Zhai in Svay Rieng Province

17. Goldrame Park Shun in Kandal Province

13 Council for the Development of Cambodia. 2017. The Special Economic Zones. http://www.cambodiainvestment. gov.kh/investment-scheme/the-special-economic-zones.html (retrieved on 1 November 2017).

14 Council for the Development of Cambodia. 2015. List of SEZ. http://www.cambodiainvestment.gov.kh/list-of-sez. html (retrieved on 1 November 2017). 


\subsubsection{Health Impact Assessment in Cambodia}

In Cambodia, Articles 6 and 7 of the Law on Environmental Protection and Natural Resources Management ${ }^{15}$ require the submission of an initial environmental impact assessment (IEIA) or an EIA to the Ministry of Environment. This represents a project approval process that was enacted in 1996.

Cambodia is in the process of developing a new EIA law that will bring stronger attention to the health impact dimension. This law also aims to integrate HIA with other impact assessments, such as EIA, social impact assessment, cumulative impact assessment, and strategic environmental assessment. It is anticipated that this will include institutional arrangements between the Ministry of Environment and Ministry of Health in order to implement HIAs effectively within these processes.

\subsection{Lao People's Democratic Republic}

\subsubsection{Special Economic Zone Development in the Lao People's Democratic Republic}

In the Lao PDR, the first SEZ decrees were established in 2003. ${ }^{16}$ Additional legislation further supporting SEZ development has been developed. ${ }^{17}$ At present, the Lao PDR identifies 10 SEZs with two economic zones defined specifically as "special:" Savan-Seno SEZ, located in the province of Savannakhet, and the Golden Triangle SEZ, located in Bokeo Province bordering Thailand and near the People's Republic of China. ${ }^{18}$ Six additional economic zones have been designated as "specific," one as a "development zone," and one as an "industrial and trade area." ${ }^{\prime 19}$ National sources identify 41 future special and specific economic zones, with the aim of developing 25 over the next decade. ${ }^{20}$

The special and specific economic zones are defined as follows (footnote 18):

In the Lao PDR, the law on investment promotion No 02/NA has identified a special economic zone means the area that the Government has determined to be developed into a new and all-around modernized town, a place to induce domestic and foreign investments which has an area of one thousand hectares

15 Royal Government of Cambodia. 1996. Law on Environmental Protection and Natural Resource Management. https://www.globalwitness.org/sites/default/files/pdfs/1996_environmental_protection_and_natural_resource_ management_law_on_1996.pdf (retrieved on 16 November 2017).

16 Prime Minister Decree 177 was designed to regulate planning, management, and promotion for both domestic and foreign investment in the SEZs. Prime Minister Decree 148 empowered SEZs to enter into joint-venture arrangements with third parties to develop the zones.

${ }^{17}$ Lao People's Democratic Republic No.02/NA: Law On Investment Promotion. Vientiane Capital, 9 April 2012. http://lao-vita.com/Legal\%20acts\%20on\%20Development\%20(Eng).pdf (retrieved on 1 February 2017).

18 Government of the Lao PDR, Ministry of Planning and Investment. 2017. Golden Triangle Special Economic Zone. http://www.investlaos.gov.la/index.php/where-to-invest/special-economic-zone?start=3 (retrieved on 16 November 2017).

${ }^{19}$ Government of the Lao PDR, Ministry of Planning and Investment. 2017. Special Economic Zone SEZ. http:// www.investlaos.gov.la/index.php/special-economic-zone-sez (retrieved on 16 November 2017)

20 Embassy of the Lao People's Democratic Republic in the United States of America. 2016. Laos to Build 41 Special Economic Zones. http://www.laoembassy.com/Laos\%20to\%20build\%2041\%20special\%20economic\%20zones. pdf (retrieved on 16 November 2017). 
and over, has the special promotion policy and autonomous economic and financial system; and to be a small administration unit having the system to ensure peace and security and sustainable environment protection.

A specific economic zone means the area that the Government has determined as industrial zone, production for export zone, tourist town zone, tax free zone, technology and information development zone, border economy zone, etc.

\subsubsection{Health Impact Assessment in the Lao People's Democratic Republic}

In March 2006, the Government of the Lao PDR introduced the National Policy on Health Impact Assessment under the Decree of Prime Minister on the Declaration of Use and Implementation of National Policy on HIA. The general objective of the national HIA policy is to "contribute substantially to poverty alleviation and to the sustainability of development in the Lao PDR, through the timely identification of adverse health effects of development and opportunities for health protection and promotion in the planning, design and operation of projects and programs and in the formulation and adjustment of development policies."21 In addition, the HIA policy seeks to eliminate and/or mitigate all negative impacts related to health associated with development projects (footnote 21).

\subsection{Myanmar}

\subsubsection{Special Economic Zone Development in Myanmar}

In 2014, a legal framework for SEZs was established under the Myanmar Economic Zone Law (footnote 3). Myanmar's legal framework consists of the SEZ law, SEZ rules, and other relevant special laws regarding land, environment, and labor. ${ }^{22}$ SEZs established governing bodies that facilitate SEZ investment, issue government SEZ approvals and enforce environmental and labor standards. Article 83 of the Environmental Impact Assessment (EIA) Procedure identifies that "an SEZ Permit can only be granted to a Developer after the issuance of an Environmental Compliance Certificate by the Environment Ministry" (footnote 22).

As of 2016, Thilawa SEZ has been developed in Myanmar with two additional zones in the planning phase (footnote 3). They are all located in coastal regions and have separate management committees. The SEZs include the following:

- Thilawa SEZ is closely located to the nation's business center of Yangon (18 kilometers from downtown core) and is the only functioning and successful SEZ in Myanmar that is operational. The development of Thilawa SEZ is set to be completed over two phases (zone A and zone B). Zone A of Thilawa SEZ (409 hectares) has been completed with businesses focusing on high-tech infrastructure, residential and commercial areas, logistics, and export industrial projects. Zone B of Thilawa SEZ

${ }^{21}$ Government of the Lao PDR, Ministry of Health. 2006. National Policy on Health Impact Assessment. Vientiane: Dalaloy, P.

22 International Commission of Jurists. 2017. Special Economic Zones in Myanmar and the State Duty to Protect Human Rights. Geneva. https://www.icj.org/myanmar-amend-special-economic-zones-law-to-protect-human-rightsnew-icj-report/ (retrieved on 1 November 2017). 
(201 hectares) will include construction and drain projects and similar businesses. Investors currently occupy $98 \%$ of Zones A and B with infrastructure in place. Completion of the zone is set for the middle of 2018. The Thilawa SEZ Management Committee was established in September 2013 with reorganization occurring in 2016.

- Dawei SEZ is a deep-sea port and is the western terminus of the GMS corridor. It is not yet operational. The Dawei SEZ Management Committee was established in September 2013 with reorganization occurring in 2016. When developed, it will be one of the largest SEZs in Southeast Asia linking the GMS with Africa, Europe, India, and the Middle East.

- Kyaukphyu SEZ is located in Rakhine Province and began construction in November 2014. It is currently not operational. The Kyaukphyu SEZ Management Committee was established in January 2014 with new governmental reorganization occurring in 2016.

Like other GMS countries, Myanmar's SEZ Law provides a One Stop Service Centre for SEZ operators and businesses. This service exists in each SEZ and is governed by a separate management committee made up of various government departments to provide investors with necessary services in one location (footnote 22).

\subsubsection{Health Impact Assessment in Myanmar}

Health is currently integrated within Myanmar's EIA process with a recent notification issued by the Ministry of Natural Resources and Environmental Conservation that includes a focus on physical, biological, social, economic, and cultural determinants. ${ }^{23}$ In terms of incorporating HIA within the EIA process, HIA guidance relies on the International Finance Corporation's 2009 HIA guidance document ${ }^{24}$ along with a good practice guidebook on community health produced by the International Council on Mining and Metals. ${ }^{25}$ Myanmar is currently engaged in building HIA capacity within the country with a focus on training and the potential development of a country-specific HIA guideline.

\subsection{Thailand}

\subsubsection{Special Economic Zone Development in Thailand}

The Government of Thailand established the Special Economic Zone Policy along with a Policy Committee for Special Economic Zones (PCSEZ) to promote the country's regional economic development, as well as establish important business connections between Thailand and neighboring countries. ${ }^{26}$ SEZs in Thailand are defined as (footnote 9):

${ }^{23}$ Government of Myanmar, Ministry of Natural Resources and Environmental Conservation. 2015. Myanmar Environmental Impact Assessment Procedures. http://www.myanmar-responsiblebusiness.org/resources/ environmental-impact-assessment-procedures.html (retrieved on 16 November 2017).

${ }^{24}$ International Finance Corporation. 2009. Introduction to Health Impact Assessment. Washington, DC.

${ }^{25}$ International Council on Mining and Minerals (ICMM). 2010. Good Practice Guidance on Health Impact Assessment. London, UK.

${ }^{26}$ Government of Thailand, Board of Invesment. 2015. A Guide to Investment in the Special Economic Development Zones. http://www.boi.go.th/upload/content/BOI-book\%202015_20150818_95385.pdf (retrieved on 1 February 2018); J. Burabhasikhrin. 2016. Thailand Introduces Economic Zones. https://tax.thomsonreuters.com/blog/ onesource/thailand-introduces-special-economic-zones/ (retrieved on 7 July 2017); Thailand Board of Investment. 2015. A Guide to Investment in the Special Economic Development Zones. Bangkok. http://www.boi. go.th/upload/content/BOI-book\%202015_20150818_95385.pdf (retrieved on 11 July 2017). 
zones which are to be supported with investment because they will be granted with special privileges for business enterprises promoted by the Government. Investors will be facilitated in their investments via contact with the One Stop Service Centre and they will be offered tax incentives, financial measures, management of the daily commute of foreign labor to work and the allocation of rented areas.

Thailand's SEZs are governed by the Industrial Estate Authority of Thailand (IEAT) and Thailand's Board of Investment (BOI), which are state enterprises that operate under the authority of the Ministry of Industry. ${ }^{27}$ In addition, under the jurisdiction of Thailand's BOI, the PCSEZ is responsible for planning, monitoring, and evaluating SEZ projects; SEZ associated financial and administrative matters; land and environmental impacts in SEZ areas; and SEZ-related legal and technical issues. ${ }^{28}$

There are currently two types of SEZs in Thailand: border SEZs and cluster-based SEZs. ${ }^{29}$ In 2015, 10 SEZs were established in border provinces as production hubs promoting economic connectivity with nearby Association of Southeast Asian Nations (ASEAN) member states. ${ }^{30}$ They have been strategically established to stimulate economic development along border regions to reduce regional disparities. ${ }^{31}$ These border SEZs are defined by province rather than by a border crossing point. Border SEZs cover a total area of 2,932 square kilometers $\left(\mathrm{km}^{2}\right)$, spanning 23 districts and 90 subdistricts (footnote 3). Border SEZs will involve labor-intensive industries requiring foreign workers from neighboring regions. ${ }^{32}$

The development of border SEZs in Thailand is set to occur over two phases. The first phase of SEZ development began in 2014 and has involved the following provinces: Tak $\left(1,419 \mathrm{~km}^{2}\right)$, Mukdahan $\left(578.5 \mathrm{~km}^{2}\right)$, Sa Kaeo $\left(332 \mathrm{~km}^{2}\right)$, Trat $\left(50.2 \mathrm{~km}^{2}\right)$, and Songkla $\left(552.3 \mathrm{~km}^{2}\right) .^{33}$ The first phase development is currently under way with operations expected to begin in $2018 .{ }^{34}$ The second phase was established in 2016 and includes the construction of an additional

27 Thailand Board of Investment. 2015. A Guide to Investment in the Special Economic Development Zones. Bangkok.

${ }^{28}$ Footnote 27; Thailand Board of Investment. 2017. A Guide to the Board of Investment 2017. Bangkok. http://www. boi.go.th/upload/content/BOI_A\%20Guide_2017_EN_20171213_99469.pdf (retrieved on 1 February 2018).

${ }^{29}$ P. Vimolsiri. 2015. Enhancing Infrastructure Development for Thailand's Future Growth. http://www.boi.go.th/ upload/content/5.\%20Enhancing\%20Infrastructure\%20Development\%20f_92919.pdf (retrieved on 10 July 2017).

${ }^{30}$ Footnote 26; Siam Commercial Bank (SCB) Economic Intelligence Center. 2015. Thailand's Special Economic Zone-National Roadmap and New Opportunities to Watch Out. Bangkok. https://www.scbeic.com/en/detail/file/ product/1167/elpnj4j498/EIC\%20Note_EN_SEZ_20150121.pdf (retrieved on 7 July 2017); Asian Development Bank. 2015. Asian Economic Integration Report 2015: How Can Special Economic Zones Catalyze Economic Development? Manila. https://www.adb.org/sites/default/files/publication/177205/asian-economic-integrationreport-2015.pdf (retrieved on 7 July 2017).

${ }^{31}$ Siam Commercial Bank (SCB) Economic Intelligence Center. 2015. Thailand's Special Economic Zone-National Roadmap and New Opportunities to Watch Out. Bangkok; Government of Thailand, Department of Foreign Trade. 2016. Guide for Investors: Thailand Special Economic Zones. Bangkok; C. Krainara. 2016. Policy Analysis on Development of Special Border Economic Zones in Thailand. Doctoral dissertation. Phathumtani: Asian Institute of Technology. https://www.researchgate.net/publication/297347110_Policy_Analysis_on_Development_of_ Special_Border_Economic_Zones_in_Thailand (accessed 7 July 2017).

32 Thailand Board of Investment. 2015. Thailand Moving Ahead with Cluster Development. Bangkok. http://www.boi. go.th/upload/content/BOI-brochure-cluster\%20area-EN-20151116_53354.pdf (retrieved on 10 July 2017).

${ }^{33}$ Footnote 3; J. Burabhasikhrin. 2016. Thailand Introduces Economic Zones. https://tax.thomsonreuters.com/blog/ onesource/thailand-introduces-special-economic-zones/ (retrieved on 7 July 2017).

${ }^{34}$ Industrial Estate Authority of Thailand. 2015. Special Economic Zones. http://ieat.go.th/en/sez (retrieved on 7 July 2017); Oxford Business Group. 2016. The Laws behind Special Economic Zones in Thailand. https:// www.oxfordbusinessgroup.com/analysis/zones-productivity-benefits-locating-business-special-economic-zone (retrieved on 7 July 2017). 
five SEZs: Nong Khai $\left(437.7 \mathrm{~km}^{2}\right)$, Narathiwat $\left(235.2 \mathrm{~km}^{2}\right)$, Chiang Rai $\left(1,523.6 \mathrm{~km}^{2}\right)$, Nakhon Pathom $\left(794.8 \mathrm{~km}^{2}\right)$, and Kanchanaburi $\left(552.3 \mathrm{~km}^{2}\right)$ (footnote 33$)$.

In 2016, the BOI identified 23 business groups to be supported in border SEZs: ${ }^{35}$

- agricultural and fishery industry, including related businesses;

- ceramics products;

- textile, clothing, and leather industry;

- household furniture industry;

- jewelry and accessories industry;

- medical equipment manufacture;

- motor vehicles, machinery, and parts industry;

- electrical appliances and electronics industry;

- production of chemical substances and plastics;

- medicine manufacture;

- logistics business;

- industrial estates or zones;

- activities that promote and support tourism;

- freeze-dried plants and silos;

- production of products made from agricultural by-products or agricultural waste material;

- animal food production;

- construction materials and compressed concrete;

- metal structures for construction work and industry;

- printing materials;

- skin cosmetics;

- plastic products for consumer goods;

- production of items made from fiber or paper; and

- the development of factory buildings and/or goods warehouses.

A cluster-based economic zone represents a concentration of "interconnected businesses and related institutions that operate with the same geographic areas" (footnote 32). The cluster economic zone relies on linkages between manufacturers, suppliers, supporting industries, research and academic institutions, and public and private organizations within its associated regions (footnote 32). Cluster-based SEZs are generally located inland and focus on future industries that require research and development, advanced technology, and minimum labor. ${ }^{36}$

\subsubsection{Health Impact Assessment in Thailand}

In Thailand, the HIA is mandated as part of the National Health Act. ${ }^{37}$ Health and health equity play an integral role in Thailand's HIA, which is considered a participatory tool and a

35 A. Pattanapanchai. 2016. Thailand's Investment Policies Update. http://www.boi.go.th/upload/content/Amcham Investment_Policies_Update_9Aug16_22623.pdf (retrieved on 10 July 2017).

36 Thailand Board of Investment. 2015. BOI Cluster Policy. http://www.boi.go.th/upload/content/BOI_Cluster Policy_for_Aerospace_AMCHAM_December2015_55326.pdf (retrieved on 10 July 2017).

${ }^{37}$ W. Phoolcharoen, D. Sukkumnoed, and P. Kessomboon. 2003. Development of Health Impact Assessment in Thailand: Recent Experiences and Challenges. Bulletin of the World Health Organization. 81 (6). pp. 465-7; M. Birley. 2012. Health Impact Assessment, Principles and Practice. New York, NY: Earthscan; Government of Thailand. 2007. National Health Act, BE 2550. Bangkok: National Health Commission Office. http://www.nationalhealth.or.th (accessed July 2017). 
process of society. ${ }^{38}$ On 19 March 2007, Thailand's National Health Act B.E. 2550 enclosed two significant laws with regard to use and implementation of the HIA: Section 11 and Section 25 (5). Section 11 provides individuals the right to request and participate in the HIA of a public policy program or project (footnote 39):

Section 11. An individual or group of people has the right to request for an assessment and participating in the assessment of health impact resulting from a public policy. An individual or a group of people shall have the right to acquire information, explanation and underlying reasons from state agency prior to a permission or performance of a programme or activity which may affect his or her health or the health of a community, and shall have the right to express his or her opinion on such matter.

Section 25 (5) identifies the National Health Commission (NHC) as responsible for prescribing rules and procedures for the monitoring and evaluation public policies through an HIA lens (footnote 39):

Section 25 (5). National Health Commission (NHC) shall have powers and duties to prescribe rules and procedure on monitoring and evaluation in respect of national health system and the impact on health resulting from public policies, both in the level of policy making and implementation.

These laws were further supported by the establishment of Sections 58 and 77 of the Constitution of the Kingdom of Thailand B.E. 2560 that was enacted on 6 April 2017. ${ }^{39}$ Section 58 of the Constitution describes the state's responsibility of undertaking impact assessments and provides Thai citizens the right to receive information, explanation, and justification for any local or national government project or activity that may impact and/or affect health (footnote 40):

Section 58, Paragraph 1. In regard to any undertaking by the State or that the State will permit any person to carry out, if such undertaking may severely affect the natural resources, environmental quality, health, sanitation, quality of life or any other essential interests of the people or community or environment, the State shall undertake a study and assess the impact on environmental quality of health of the people or community and shall arrange a public hearing of relevant stakeholders, people and communities in advance in order to take them into consideration for the implementation or granting of permission as provided by the law.

Section 58, Paragraph 2. A person and community shall have the rights to receive information, explanation and reasons for a State agency prior to the implementation or granting of permission under paragraph one.

Section 58, Paragraph 3. In the implementation or granting of permission under paragraph one, the State shall take precautions to minimize the impact

${ }^{38}$ Government of Thailand. 2007. National Health Act, BE 2550. Bangkok: National Health Commission Office. http://www.nationalhealth.or.th (accessed July 2017).

${ }^{39}$ Government of Thailand. 2017. Constitution of the Kingdom of Thailand, B.E. 2560 (2017). Bangkok: Bureau of Committee 3, The Secretariat of the House of Representatives. http://www.constitutionnet.org/ (retrieved on 15 October 2017). pp. 19-25. 
on people, community, environment, and biodiversity and shall undertake to remedy the grievance or damage for the affected people or community in a fair manner without delay.

Section 77 of the Constitution further supports Section 58 and states that prior to the enactment of any new law the state must conduct a thorough due diligence assessment that involves stakeholder engagement and disclosure of information (footnote 40):

Section 77, Paragraph 2. Prior to the enactment of every law, the State should conduct consultation with stakeholders, analyze any impacts that may occur from the law thoroughly and systematically, and should also disclose the results of the consultation and analysis to the public, and take them into consideration at every stage of the legislative process. When the law has come into force, the State should undertake an evaluation of the outcomes of the law at every specified period of time, for which consultation with stakeholders shall be conducted, with a view to developing all laws to be suitable to and appropriate for the changing contexts.

In 2009, Thailand's Health Impact Assessment Coordinating Unit (HIACU) published rules and procedures for HIAs. ${ }^{40}$ Thailand's HIA process is required (footnote 38):

1. in the case of a project or activity which may seriously affect communities. This is in conjunction with [Section 58 of the 2017] Constitution;

2. at the level of public policy or planning which may seriously affect communities in the future;

3. in accordance with Section 11 of the National Health Act 2007; and

4. as a joint learning process of the society. [This involved promoting] mutual learning in communities and [supporting] participation in decision making in policy, project and activity.

\subsection{Viet Nam}

\subsubsection{Special Economic Zone Development in Viet Nam}

Viet Nam is home to over 400 industrial zones and SEZs, $89 \%$ of which are privately owned and $11 \%$ of which are publicly owned. These include 18 coastal economic zones, 27 border economic zones, and 325 industrial zones. ${ }^{41}$

SEZs in Viet Nam are governed by the Department for Economic Zones Management, a subsidiary of the Ministry of Planning and Investment. The Department for Economic Zones Management is comprised of the Director General and a number of deputy directors. It was established on 14 April 2009 and was initiated to ${ }^{42}$

${ }^{40}$ Health Impact Assessment Coordinating Unit (HIACU). 2010. Thailand's Rules and Procedures for the Health Impact Assessment of Public Policies. Nonthaburi: National Health Commission Office.

${ }^{41}$ Government of Viet Nam, Ministry of Planning and Investment. 2017. Special Economic Zones Should Enjoy Special Rules: PM. http://www.mpi.gov.vn/en/Pages/tinbai.aspx?idTin=37684 (retrieved on 1 November 2017).

${ }^{42}$ Government of Viet Nam, Ministry of Planning and Investment. 2015. Function, Responsibilities and Structural Organization of the Department for Economic Zones Management. http://www.mpi.gov.vn/en/Pages/tinbai. aspx?idTin $=30032 \&$ idcm $=108$ (retrieved on 1 November 2017). 
- formulate master plans for economic zones throughout the country for the Ministry of Planning and Investment and submit these plans to the Prime Minister for approval;

- provide direction, supervision, and inspection during the implementation of master plans;

- make necessary adjustments to economic zone development proposals and plans;

- supervise the evaluation of state management activities of economic management boards;

- reconcile any problems or issues that pertain to the economic zone development;

- preside over the development and management of information systems for economic zones in the country;

- serve as the coordinator for the supervision and evaluation of state management activities in relation to economic management boards;

- provide guidance on economic zone policies in accordance with statutory regulations on investment;

- collaborate with other ministries to assess the socioeconomic efficiency of domestic and foreign investment; and

- fulfill any other duties assigned by the Ministry of Planning and Investment.

\subsubsection{Health Impact Assessment in Viet Nam}

The HIA has been supported in Viet Nam since 2007 with the Law on Prevention and Control of Infectious Diseases requiring that projects related to urban or industrial areas, residential parks, or infectious disease health facilities require an HIA prior to construction.

In 2012, the Viet Nam Health Environment Management Agency (VIHEMA) developed an HIA guideline with attention to characterizing

- general health risk factors;

- vulnerable communities;

- disaggregated risk factors by community group;

- risk factors that are project-phase-specific (feasibility, construction, and operation);

- health impacts with focus on

- infectious disease,

- noninfectious disease,

- malnutrition,

- injury, and

- sociopsychological disorders;

- relevant health indicators;

- published relevant health research;

- qualitative data from district health care staff at the project site;

- the state of health care facilities;

- environmental health risks including the geographical distribution, potential risk areas for transmission and exposure as well as seasonal distribution;

- the source of impacts related to domestic water and wastewater sources;

- the source of impacts related to air quality in residential areas;

- the source of impacts related to solid waste production and management associated with a project;

- other sources of health risks such as the social environment, transportation, exposure to solar radiation, and vector-borne disease; 
- institutional risk factors including the capacity of related units and organizations; clearly pointing out strengths or weaknesses of public or private organizations, organizations responsible for health protection before project implementation;

- relevant policies and legislation; and

- risk for medical service burden that may arise due to the project.

In 2014, the environmental protection legislation was updated to include population health issues. Article 22 of the new Environmental Protection Act would include

- assessment of waste sources, and the impact of the project on the environment and community health;

- assessment, forecast, and determination of measures for managing the risks of the project posed to environment and community health; and

- measures for minimizing the impact on environment and community health.

This was further supported by Decree No. 27/2015/TT-BTNMT on strategic environmental assessment, environmental impact assessment, and environmental protection, which cites that one of the most critical impacts requiring assessment are those associated with public health. 


\section{Health Opportunities and Risks Associated with Special Economic Zones}

The establishment of an HIA framework for SEZs is particularly important as the nature of SEZs can hold unique health risks for both workers and communities. These zones tend to be located outside of capital regions, and, as such, infrastructure, services and knowledge, and attitudes and practices around health are generally less developed than in urban settings. Also, SEZs are strategically placed to take advantage of cross-border collaboration, and consequently transient migrant populations are to be expected. This can place added pressure on health risks as, at present, a coordinated health system across the GMS addressing universal health coverage and surveillance for major communicable and infectious diseases is lacking. The very nature of businesses within an SEZ also varies, ${ }^{43}$ both by industry type and by nationality. SEZs are and will be culturally diverse locations, and, in taking into consideration all of the above, can also hold unique risks to local communities and workers if left unidentified and unmanaged.

In a well-functioning SEZ (Figure 2), health opportunities can stem from

- universal health coverage for workers and community members;

- a harmonized health information and surveillance system;

- meeting of basic essential needs (clean water, shelter, sanitation, security, and food safety are accessible);

- proper zoning of residential and commercial, recreation, and industrial areas;

- the capacity of the emergency preparedness and response sector to respond to both industrial and community incidents;

- industrial traffic having designated routes and road infrastructure in good, safe condition;

- strategic resettlement of households, when required, with infrastructure complete and in excellent condition;

- separate and safe industrial and public waste management;

- safe worker behavior on- and off-site;

- peaceful cohabitation of workers and community members;

- strategic location and good condition of worker accommodations; and

- protection of cultural and spiritual sites.

In a poorly functioning SEZ (Figure 2), health risks can stem from

- mixing of residential and industrial uses of land (the lack of appropriate buffer zones);

- environmental issues such as airborne emissions, water pollution, noise, light, and vibration;

- inadequate health services for mobile and migrant workers and community members;

${ }^{43}$ Depending on the nature of the zone, businesses can include but are not limited to manufacturing, heavy industry (refining), tourism, and textile or garment. 
- inability of emergency preparedness and response sector to respond appropriately to industrial and community incidents;

- conflicts between local residents and projects;

- lack of cohesion between community members and workers;

- resettlement that happens multiple times and infrastructure that remains unfinished;

- worker accommodation that is in poor condition;

- nonexistent waste management strategies;

- disorganized and chaotic traffic;

- workers not being equipped with safe working conditions or provided the basics to be safe on- and off-site;

- poor coping and personal health practices, such as alcohol and drug abuse;

- human trafficking;

- impoverishment; and

- lack of basic needs being met including access to safe water, sanitation, shelter, security, and safe food.

The objective of this HIA framework is to ensure SEZ development results in both improved business and health opportunities.

Figure 2. Health Opportunities and Risks Associated with Special Economic Zone Development

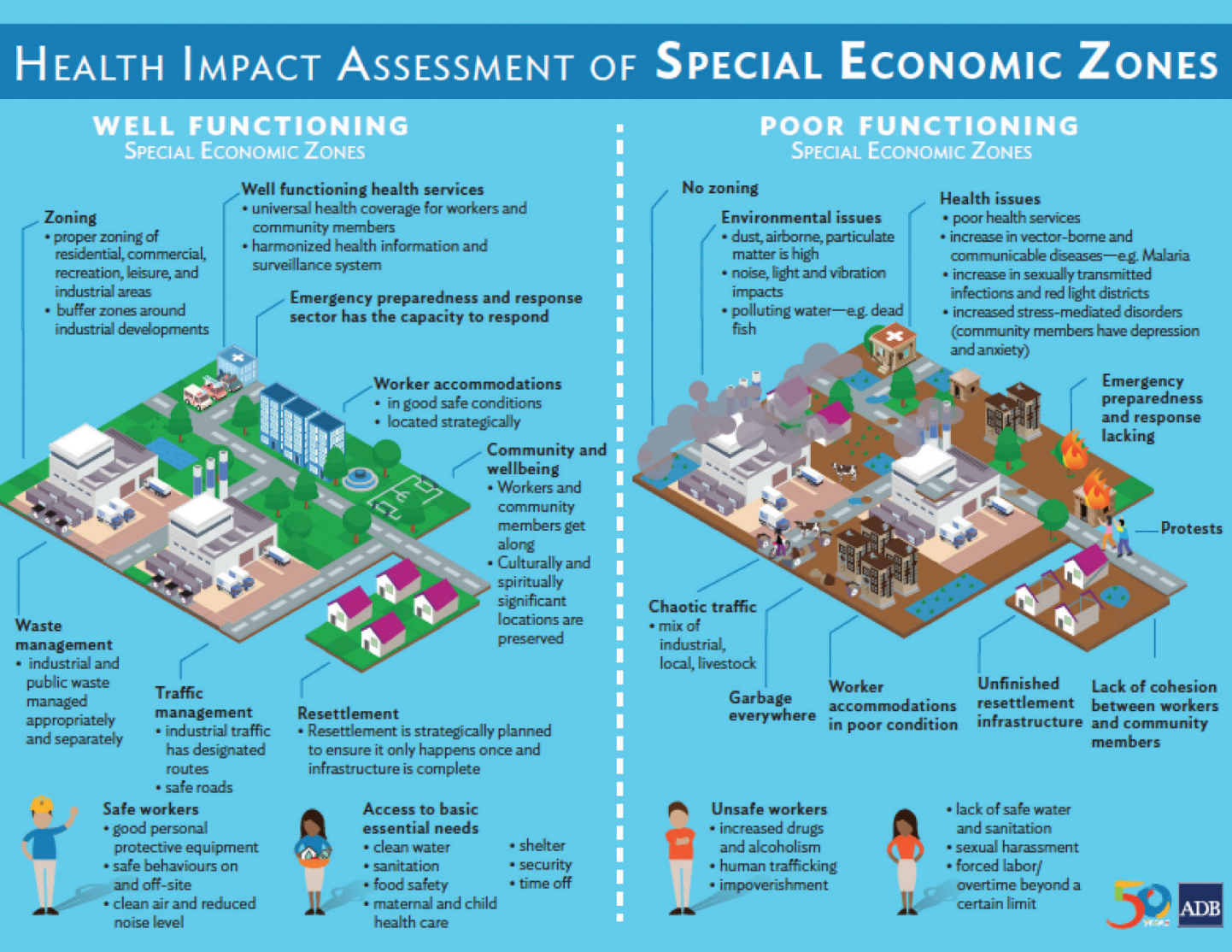

Note: The above opportunities and risks inform core elements that should be considered in health impact assessment work for special economic zones.

Source: Authors. 


\section{A Health Impact Assessment Framework for Special Economic Zones}

Given the organizational and management diversity for SEZs across the GMS, the HIA framework (Figure 3) is focused on regions, communities, and areas supporting SEZ development rather than individual SEZs (if isolated) or SEZ projects. The framework places people directly affected by or associated with SEZ development at the center, as they directly interface with the SEZ and its associated facilities and activities. SEZ-affected people could be considered those who

- have been resettled as a result of SEZ development;

- have their livelihoods positively impacted due to zone development (economic opportunities);

- have their livelihoods negatively impacted due to zone development (economic displacement);

- live adjacent to a zone;

- live adjacent to worker accommodation facilities for the SEZ;

- live along economic and transportation corridors associated with SEZ-related industrial traffic;

- work in the construction of the zone and associated businesses; or

- work in the established SEZ businesses.

SEZ workers (including those who are involved in the construction of the SEZ and associated facilities) are a critical population within the area supporting SEZ development. The safety, security, and fair treatment of workers are fundamental toward maximizing economic growth, income generation, and health opportunities in SEZs. There may be gender-based risks to consider as, depending on the sector, the workforce is likely to be gender-specific. For instance, in heavier industrial settings and during the construction of businesses within the zone, the workforce will be primarily male. During operation, female employees may represent up to $90 \%$ of the workforce. ${ }^{44}$ The districts supporting SEZ development also represent home to workers (at least part-time), and how and where they spend their time off can have both positive and negative impacts to people within these areas. Conversely, baseline health conditions present within the SEZ-supporting region can hold distinct risks to worker health. As such, workers are recognized as a fundamental part of the SEZ community.

The framework further recognizes that officials from different ministries, sectors, and other stakeholders at the regional and national level can influence both the implementation and optimization of HIAs for SEZs. People within these institutions are essential in maximizing health opportunities while identifying and managing health risks for current and future SEZ development.

${ }^{44}$ International Labour Organization. 2008. Report of the InFocus Initiative on Export Processing Zones: Latest Trends and Policy Developments in EPZs. http://www.ilo.org/gb/WCMS_090223/lang--en/index.htm (retrieved on 12 December 2017). 
Applying the framework for SEZ development requires agreement on core elements to be the focus for HIA work. These elements are further elaborated on in section 5.1. It also requires implementation efforts to obtain results. Implementation efforts (characterized by inputs and processes) require human and financial contributions to support the establishment, implementation, and success of an HIA within an SEZ. Results associated with the HIA framework are described in terms of outputs, outcomes, and impacts.

Figure 3. Health Impact Assessment Framework for Special Economic Zone Development

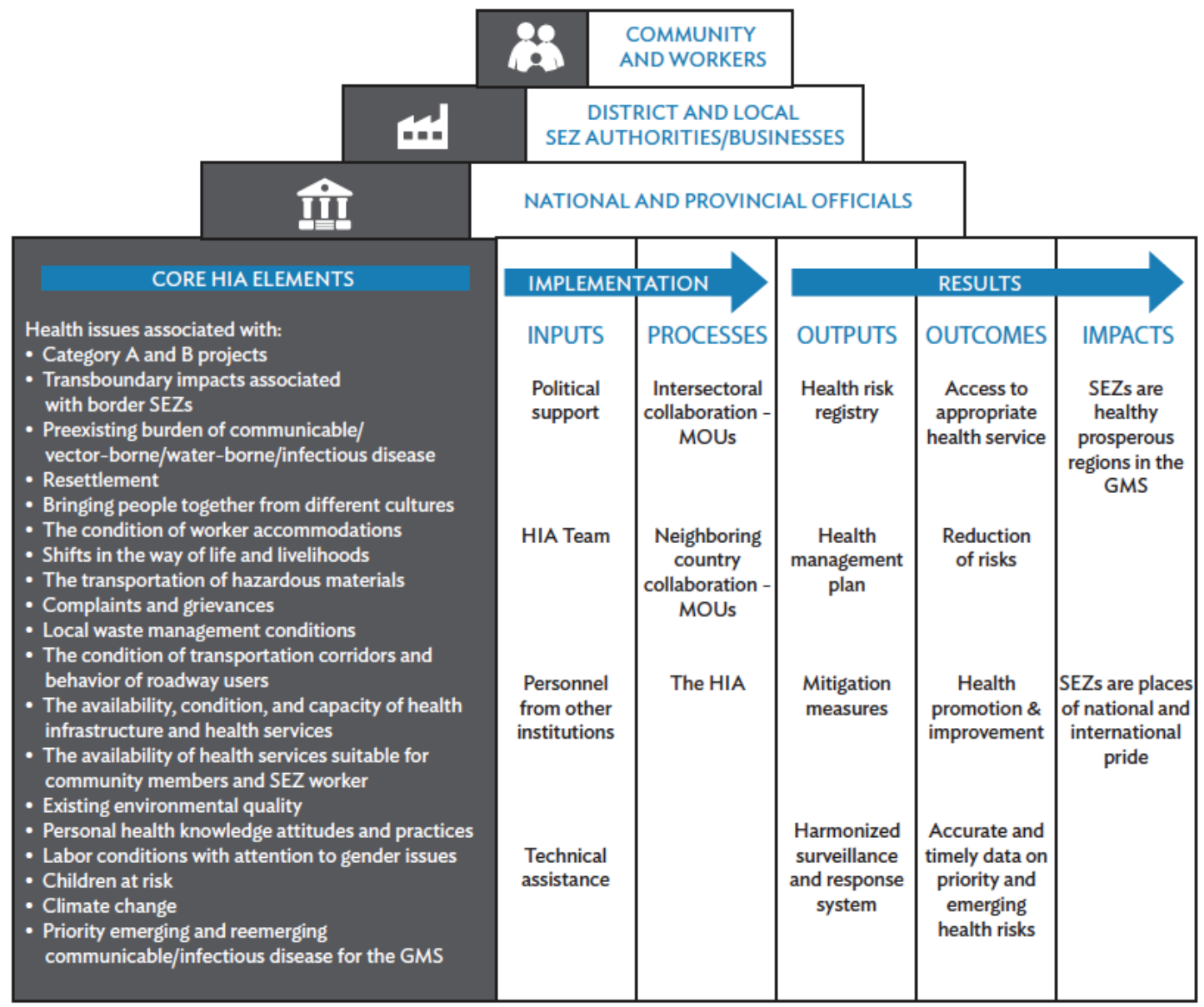

HIA = health impact assessment, GMS = Greater Mekong Subregion, MOU = memorandum of understanding, $\mathrm{SEZ}=$ special economic zone.

Source: Authors.

\subsection{Inputs}

The successful application of HIAs for SEZs and economic corridors hinges on political support from all government agencies associated with SEZ development, which includes (but is not limited to) investment, the environment, labor and working conditions, emergency preparedness and response, resettlement, transportation, and power. Political support is 
required to commit to the relevance of health and to the HIA as a management tool. This support is also required to commit to participating and assisting, where relevant, in the HIA phases.

Regardless of how the HIA is supported in-country, the most successful institutional arrangement for HIAs for preexisting SEZs and newly established or proposed SEZs that have yet to undergo development would see officials from the health ministry, the SEZ authority, and the natural resources or environment ministry form the core HIA team. For border communities along economic corridors, officials from the health ministry would be appropriate. These ministries and government authorities will need to dedicate financial and human resources to establish the HIA team and undertake the HIA work. Given that SEZ development will be emerging rapidly over the next decade and that the HIA process cannot be static, it is recommended that personnel be senior-level officials capable of advocating resources and decisions, if needed, to address risks or impacts in a timely manner.

Human and financial resources are also required from other aforementioned governmental agencies. Dedicated staff is needed to share information and data with the HIA team, participate in HIA phases, and assist in the development and implementation of management measures to maximize health promotion as well as address risks and impacts. It is also recommended that personnel from other government agencies be senior-level officials.

Technical assistance may also be required at the early stages of applying the health impact assessment as a management support tool. While all GMS countries have had the opportunity to benefit from HIA capacity-building, the application of the HIA as a management support tool for an important investment and business area has a slightly different focus. Technical assistance should ensure all members of the HIA team

- understand the unique focus of this type of HIA,

- are able to successfully prioritize health risks to maximize benefits for both community members and the SEZ business community, and

- are fully supported during the first round of HIA activities related to SEZ development to ensure that the multidisciplinary process is successful.

\subsection{Processes}

With political support, human and financial resources, and technical assistance in place, successful implementation of the HIA for SEZ development will require formalized agreement on participation, sharing of information, and commitment to response actions, where needed. Within the country, memorandums of understanding (MOUs) should be established between the ministries responsible for the HIA team and other government agencies that will support dedicated personnel to participate, share knowledge and information, and assist in other aspects of the HIA process.

Memorandums of understanding are also required with neighboring countries. These should focus on data-sharing and response to critical existing and potential emerging communicable, vector-borne, or infectious diseases, with a commitment to addressing the need for universal and/or harmonized health coverage for mobile workers from other countries. 
Conducting the health impact assessment itself is also a process. Given that the nature of SEZ and economic corridor use will change over time, the HIA will be accomplished at a strategic level, allowing for the rapid identification of critical issues requiring management. Also, given the development and management of an SEZ represents arguably a policy event with multiple projects, the HIA process needs to be responsive and continual as this type of development is dynamic and the zone will continue to change and grow. New business will emerge, and population demographics will change over time. As such, it can be anticipated that health risks will also change.

There are five main phases of the HIA (Figure 4) process. Initial phases of an HIA generally involve a screening phase to establish the health relevance of a policy, program, or project. In the case of SEZ development and border communities along economic corridors, the health risks of significant international economic development in areas outside of the capital regions across the GMS and among transient populations in border regions are relevant. It is therefore recommended that the initial focus be placed on scoping and baseline data collection. This will be accomplished by the HIA team with support from other agencies.

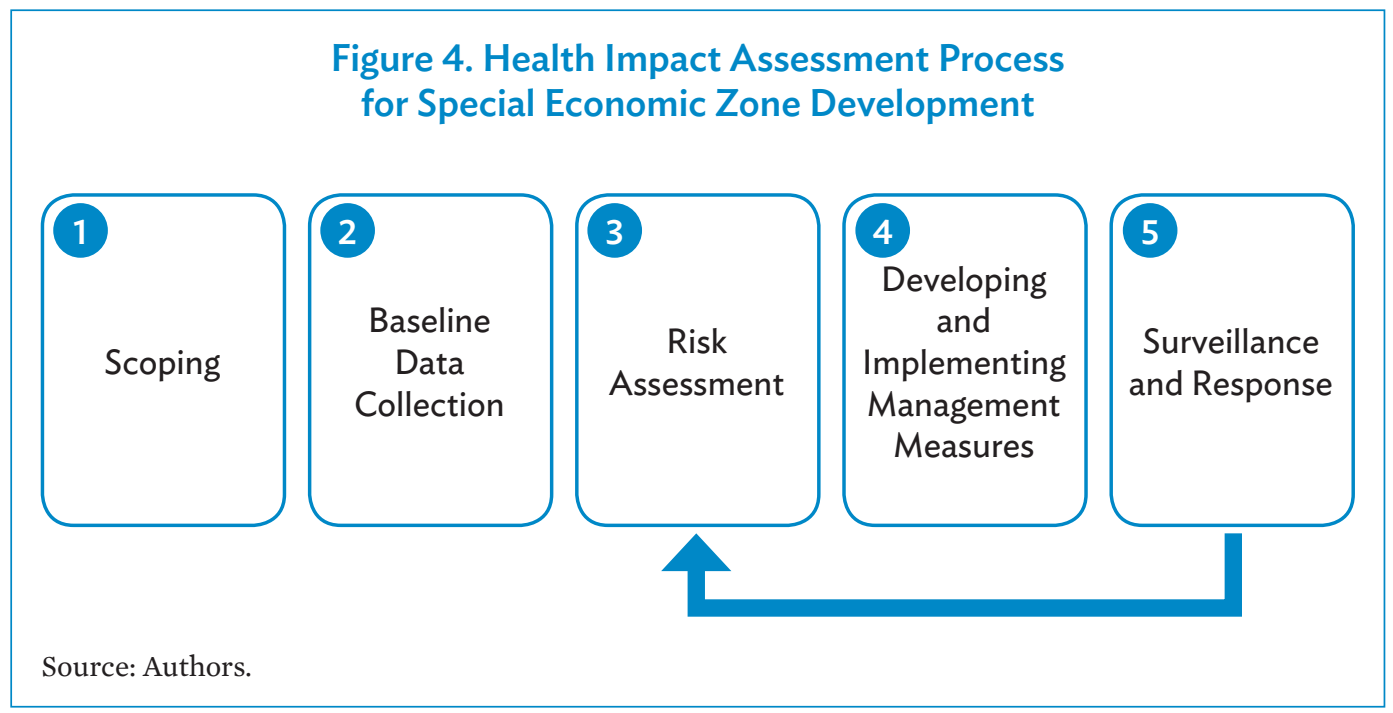

The next phases are focused on risk assessment and development and implementation of mitigation and management measures. This phase will be accomplished in collaboration between the HIA team and officials from other relevant agencies, on the one hand, and the private sector, on the other. This is to ensure associated institutions are aware of present or potential health risks and can participate in the development and implementation of appropriate management measures. The final phase involves the development and implementation of a surveillance and response system. Collaboration between the HIA team, relevant authorities, and the private sector is again required to have access to the relevant data and to respond effectively when required. These phases are described in more detail in section 5 . 


\subsection{Outputs}

The abovementioned inputs and processes will contribute to numerous positive results for SEZ-associated districts and businesses alike. Notable outputs include

- the development of a health risk registry;

- the development of a health management plan;

- the development and implementation of mitigation measures (which may include infrastructure upgrades); and

- the initiation of a harmonized surveillance and response system, both nationally and GMS-wide.

\subsection{Outcomes}

In establishing and implementing an HIA framework for communities that support SEZ development and border regions of the economic corridors, outcomes will include improved access to appropriate health services for workers and community members, a reduction of identified health risks, and initiation of mitigation and management measures. As reactive management to health issues will decrease, there will also be space for focus on health promotion and improvement. Finally, with the establishment of a harmonized surveillance and response system, accurate and timely data will be available for priority and emerging health risks.

\subsection{Impacts}

The objective of the HIA process is to optimize business and livelihood conditions within an SEZ. The SEZ will be a place of pride of the international and local community. For business, social and environmental performance policies will be realized. For community members and workers, health and determinants of health outcomes will be improved and a responsive, preventive health care system will be in place. 


\section{Health Impact Assessment Guidelines for Special Economic Zones}

There are three scenarios in which an HIA will be considered. These scenarios as described in the following will vary in terms of the resources required (Figure 5):

1. A retrospective health impact assessment will be conducted for preexisting special economic zones in order to address any current health risks and impacts and to ensure expansion plans for further development incorporate effective mitigation and health promotion actions. HIAs for preexisting SEZs will be the most detailed as there will be a number of issues to consider and data requirements will be larger.

2. A new, prospective health impact assessment will be conducted for newly proposed special economic zones or those yet to undergo significant development to ensure the zone is developed in a strategic manner that incorporates, plans for, and manages health risks, impacts, and opportunities right from the beginning. In this case, the HIA will focus on contextual conditions present in the region supporting the zone, in addition to any available information on the SEZ development plan.

3. A scoping phase of a health impact assessment for border communities along economic corridors will be conducted to allow for the identification of any potential, current, or emerging health risks as these regions face a higher likelihood for future SEZ development. The scoping phase will flag critical issues, data gaps, or inconsistencies present across countries, allowing for further development of a harmonized health surveillance system required to effectively monitor conditions and capture potential risks across time.

Figure 5. Resources (Financial and Human) Required for Health Impact

Assessment Work Associated with Special Economic Zones and Border Communities

BORDER COMMUNITIES

PROPOSED/NEW SEZs

PREEXISTING SEZs

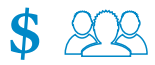

\$ \$

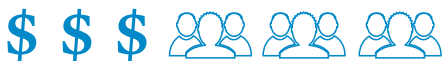

Source: Authors. 


\subsection{Scoping Phase}

Geographical scope. The scoping phase will first aim to identify the geographical scope of the HIA. It is important to identify the population directly interfacing with the SEZ and its associated facilities (e.g., dry or wet ports) and activities (e.g., transportation of goods in and out of the zone and associated facilities). SEZ-affected people could be considered those who

- have been resettled as a result of SEZ development;

- have their livelihoods positively impacted due to zone development (economic opportunities);

- have their livelihoods negatively impacted due to zone development (economic displacement);

- live adjacent to a zone;

- live adjacent to worker accommodation facilities for the SEZ;

- live along economic and transportation corridors associated with SEZ-related industrial traffic;

- work in the construction of the zone and associated businesses; or

- work in the established SEZ businesses.

Map. A deliverable of this scoping activity is a map. It should outline all SEZ development areas, associated facilities, transportation corridors, populated areas associated with SEZ development and associated facilities, worker accommodations, and other important features of the area (e.g., waste facilities, border crossings, hospitals and clinics, resettlement areas).

Relevance. The next phase of scoping will investigate issues known to hold community and worker health and safety risks to determine their relevance. This investigation process uses a health and safety matrix adapted from international occupational health and safety practices (Table 1). This process allows for the strategic and clear identification of safe and unsafe conditions present within the SEZ, areas supporting SEZ development, or economic corridors that may pose health and safety risks to community members and workers.

Table 1. Scoping Phase: Investigation into the Special Economic Zone Context

\begin{tabular}{|c|c|c|c|}
\hline Issue & \multicolumn{2}{|c|}{ Response } & Comment \\
\hline $\begin{array}{l}\text { In the general area supporting the SEZ, are } \\
\text { there any concerns in terms of observable } \\
\text { environmental quality? }\end{array}$ & Yes & No & \\
\hline Does the SEZ have any Category A or B projects?a & Yes & No & \\
\hline Is this a border SEZ? & Yes & No & \\
\hline $\begin{array}{l}\text { Is the } \mathrm{SEZ} \text { area prone to country priority } \\
\text { communicable/vector-borne/infectious disease? }\end{array}$ & Yes & No & \\
\hline $\begin{array}{l}\text { Has there been resettlement due to SEZ } \\
\text { development or is it planned? }\end{array}$ & Yes & No & \\
\hline $\begin{array}{l}\text { Are cultural differences present in the workforce } \\
\text { compared to the community? }\end{array}$ & Yes & No & \\
\hline
\end{tabular}

continued on next page 
Table 1 continued

\section{Scoping phased investigation into the SEZ Context}

\begin{tabular}{|c|c|c|c|}
\hline Issue & \multicolumn{2}{|c|}{ Response } & Comment \\
\hline $\begin{array}{l}\text { Are there worker accommodations associated } \\
\text { with the SEZ? }\end{array}$ & Yes & No & \\
\hline $\begin{array}{l}\text { Will the way of life of communities associated } \\
\text { with SEZ change? }\end{array}$ & Yes & No & \\
\hline Are hazardous materials used or transported? & Yes & No & \\
\hline Are there grievances regarding the SEZ? & Yes & $\mathrm{No}^{\mathrm{b}}$ & \\
\hline $\begin{array}{l}\text { Does the SEZ have policies and procedures in } \\
\text { place to ensure workers are safe and secure, and } \\
\text { their rights under national laws and international } \\
\text { conventions are protected? }\end{array}$ & Yes & No & \\
\hline $\begin{array}{l}\text { Are there national legal provisions and regulations } \\
\text { that adequately protect female workers? }\end{array}$ & Yes & No & \\
\hline $\begin{array}{l}\text { Are there national and SEZ-specific legislation/ } \\
\text { political instruments in place that ensure the } \\
\text { provision of local health services to migrant } \\
\text { workers? }\end{array}$ & Yes & No & \\
\hline $\begin{array}{l}\text { Is the SEZ area reporting on outbreaks and } \\
\text { collection of routine disease surveillance data } \\
\text { from private and public health services? }\end{array}$ & Yes & No & \\
\hline $\begin{array}{l}\text { Does the majority of households in the SEZ } \\
\text { area have access to safe water and appropriate } \\
\text { sanitation measures? }\end{array}$ & Yes & No & \\
\hline $\begin{array}{l}\text { Does the region have appropriate, sufficient } \\
\text { and separate (industrial vs. municipal) waste } \\
\text { management strategies? }\end{array}$ & Yes & No & \\
\hline $\begin{array}{l}\text { Are there buffer zones between the SEZ or SEZ } \\
\text { projects and residential areas? }\end{array}$ & Yes & No & \\
\hline $\begin{array}{l}\text { Is there emergency, preparedness, and response } \\
\text { capacity? }\end{array}$ & Yes & No & \\
\hline Are roads in good condition and traffic organized? & Yes & No & \\
\hline $\begin{array}{l}\text { Has the health status of children been improving } \\
\text { over the last } 5 \text { years? }\end{array}$ & Yes & No & \\
\hline $\begin{array}{l}\text { Do workers and community members have access } \\
\text { to appropriate and adequate health services? }\end{array}$ & Yes & No & \\
\hline $\begin{array}{l}\text { Does the area supporting SEZ development have a } \\
\text { climate change strategy? }\end{array}$ & Yes & No & \\
\hline
\end{tabular}

SEZ = special economic zone.

a Category A projects generally pose community health and safety risks. More information on Category A projects can be found at ADB. Safeguard Categories. https://www.adb.org/site/safeguards/safeguardcategories

b If no grievances have been lodged, it could be an indication that there is no system in place or individuals (community members or workers) do not feel safe to register a grievance. More information is required.

Note: Issues highlighted in orange represent potentially unsafe conditions. They require more information and will be the basis for review of data availability and quality. Issues highlighted in green can be considered safe and should be monitored over time for potential change. Issues highlighted in yellow also require more information. 
Data availability and quality. Conditions identified as unsafe are the "issues" that hold health risks and require further analysis. When an issue is identified as requiring consideration, data availability and quality will be assessed. A data availability and quality tool is presented in Table 2.

Table 2. Scoping Phase: Preexisting Data Availability and Quality Tool

\begin{tabular}{|c|c|c|c|c|c|c|c|c|}
\hline $\begin{array}{c}\text { Identified } \\
\text { Health Issue } \\
\text { of Concern }\end{array}$ & \multicolumn{2}{|c|}{$\begin{array}{c}\text { Available } \\
\text { Information }\end{array}$} & \multicolumn{3}{|c|}{ Data Quality } & \multicolumn{2}{|c|}{ Data Gap } & \multirow{2}{*}{$\begin{array}{c}\text { Data } \\
\text { Deeded }\end{array}$} \\
\cline { 2 - 10 } & Data & Source & Low & Medium & High & Yes & No & Needology \\
\hline & & & & & & & & \\
\hline
\end{tabular}

The data availability and quality tool can be used to organize information and data gathered during the scoping phase and to help identify gaps requiring additional data collection and the methodology to do so.

When assessing the quality of data, the following factors, at minimum, to consider include

- whether or not the data were collected, analyzed, and reported on by a reputable source;

- if the data are disaggregated at the appropriate level to be representative of the population of interest; and

- if the data are current.

In summary, the scoping phase sets the terms of reference for subsequent HIA phases. A main deliverable for this phase is a scoping phase report. This report should be short and succinct to focus on the key issues requiring attention, the availability and quality of data associated with these issues, and the work plan for further HIA work.

\subsection{Baseline Data Collection}

Baseline data collection will involve the collection of both leading and lagging indicators (Table 3) using a multimethod approach to understand both the contextual drivers (determinants of health) that hold influence on current health issues of concern. Both types of indicators are important, as leading indicators (such as those associated with knowledge, attitudes, and practices) will help strategically identify areas that can be strengthened to have a positive influence on health outcomes or lagging indicators (such as HIV/AIDS rates).

Potential data collection indicators associated with common issues related to SEZs that may require attention are presented in Appendix 1. These indicators will require collection, reporting, and collaboration from a number of government agencies. This is further discussed in section 5.5. Additional tools to assist in the development of the baseline condition are presented in Appendixes 2, 3, and 4. As all SEZs require accommodation for workers-either during construction of factories or the zone itself, or during operation-an assessment for worker accommodation health and safety standards has been included. Similar to other projects, community members and workers will have questions, concerns, and potential 
Table 3. Differences between Leading and Lagging Health Indicators

\begin{tabular}{|c|c|}
\hline Leading Indicators & Lagging Indicators \\
\hline Prospective-they look to the future & Retrospective-based on the past \\
\hline $\begin{array}{l}\text { Describe the context or drivers for lagging } \\
\text { indicators }\end{array}$ & $\begin{array}{l}\text { Describe outcomes (health rates) or failures } \\
\text { (death) }\end{array}$ \\
\hline $\begin{array}{l}\text { Influential-easily point to issues that need to } \\
\text { change }\end{array}$ & No influence-no idea where to begin \\
\hline $\begin{array}{l}\text { Will evolve-indicators may change; as we learn } \\
\text { more, we may need other information }\end{array}$ & Static-indicators remain the same \\
\hline
\end{tabular}

Note: It is recommended to consider both for an effective health impact assessment as a management support tool.

complaints related to SEZs. Appendix 3 provides additional information on leading tools used to develop and implement a culturally appropriate grievance mechanism. Effective grievance mechanisms can be the source of important health and safety data on emerging issues.

\subsection{Risk Assessment}

Given the strategic nature of the HIA, the risk assessment will focus on prioritizing issues and resources to address risks requiring attention. The risk assessment will be accomplished by reviewing contextual data (leading and lagging indicators) related to the issues of interest. The HIA team will compile these data and undertake a first draft of the risk assessment. This will be presented to associated SEZ authorities to involve and inform them in the ranking of present or potential health risks and to collaboratively identify and implement new management measures. A health risk assessment matrix and prioritization tool is provided in Appendix 5.

As identified in Figure 4, the HIA for SEZ is a cyclical process. For newly established SEZs that have yet to begin development, an annual risk review is recommended. However, once an SEZ begins development, or for preexisting SEZs, biannual risk review will be conducted in order to evaluate the success of mitigation measures and to capture new or reemerging issues. For border communities along economic corridors, it is also recommended that biannual risk assessments occur to ensure conditions are stable and health risks are being effectively managed.

\subsection{Development and Implementation of Management Measures}

The management of health risks in SEZ regions and economic corridors requires a systematic and collaborative approach. Health protection and promotion measures should be based on both leading and lagging data and prioritized as per risk assessment findings. These measures will be documented in an SEZ or Economic Corridor Health Management Plan. This management plan should outline, at minimum, the following: 
- the objective of the management plan;

- the organizational chart associated with the development of the management plan (who is the HIA team);

- key health issues requiring attention;

- associated mitigation measures with identification of roles and responsibilities, an implementation schedule, and resources (financial and human) required; and

- a reporting schedule (biannual or annual is recommended), with a report that highlights critical issues, documents trends in data, provides findings from the risk review (an update of the risk registry), and outlines current and new mitigation, management, and health promotion measures.

Examples of mitigation measures that would be relevant for local authorities to implement include the following:

- measures to ensure road conditions are in good order and traffic is flowing in a safe and organized fashion;

- resettlement is managed strategically to protect people's livelihood and mental wellbeing;

- emergency preparedness and response system has the capacity to respond to both industrial and community events; and

- health services have the capacity to provide appropriate services and are promoting and implementing initiatives targeting preventive healthy behaviors.

Project owners, on the other hand, should ensure worker accommodations are well managed and inspected at regular intervals for conformance with international standards ${ }^{45}$ and that workers have both an on-site and off-site code of conduct. They should also implement measures to enhance worker knowledge, attitudes, and practices on important health risks for the region. Moreover, they have the overarching responsibility to implement specific risk mitigation measures based on their business activities.

\subsection{Surveillance and Response}

Surveillance and response are a critical feature not only of the HIA, but also for enabling a predictable setting and accountability for risks, impacts, and management measures. While surveillance and response are linked with the HIA, it should be recognized that they are also a fundamental feature embedded within international standards associated with social and environmental risk management (Figure 6).

Surveillance data for the effective management of health and safety risks will be multifaceted and come from many sources including the health sector (Figure 7). These data need to be able to describe current conditions along with the contextual setting. Surveillance and response are an ongoing, dynamic, and iterative process that is responsive to growing and changing SEZ communities. It should be expected that the surveillance model will change according to conditions in the SEZ area. It needs to provide a clear process for collecting and

${ }^{45}$ International Finance Corporation and European Bank for Reconstruction and Development. 2009. Workers' Accommodation: Processes and Standards. A Guidance Note by IFC and the EBRD. Washington, DC: World Bank. http://www.ebrd.com/downloads/about/history/workers.pdf (retrieved on 16 November 2017). 
Figure 6. International Requirements for the Management of Social and Environmental Risks and Impacts

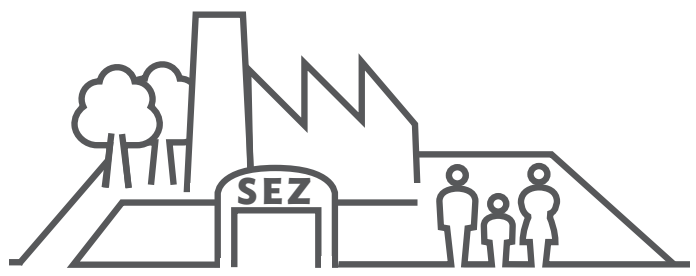

MANAGING SOCIAL AND ENVIRONMENTAL PERFORMANCE

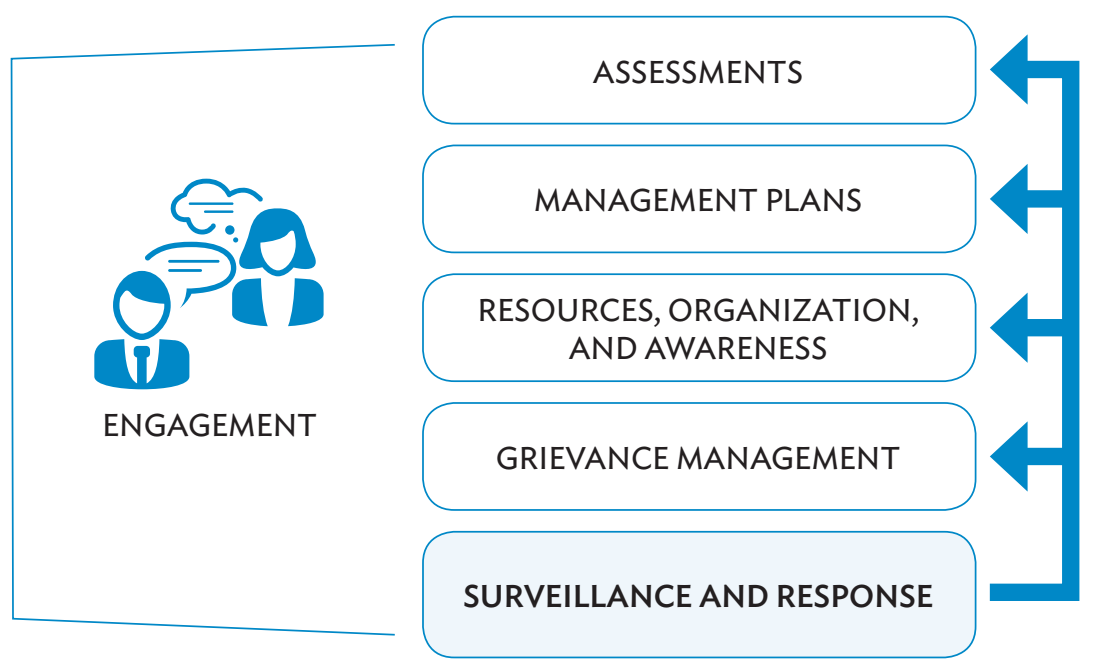

Source: Based on requirements set forth in International Finance Corporation. 2012. Performance Standards on Environmental and Social Sustainability. Washington, DC; The Equator Principles Association. 2013. Equator Principles III. http://equator-principles.com./about/; European Bank for Reconstruction and Development. 2014. Performance Requirements and Guidance. http://www.ebrd. com/who-we-are/our-values/environmental-and-social-policy/performance-requirements.html.

tracking issues related to community and worker health in an SEZ area and for measuring the effectiveness of mitigation measures identified in the HIA process. Surveillance data also can inform further investigations to identify root causes of emerging heath issues. Importantly, surveillance data feed into the risk assessment, which can trigger a new response if and when required.

The responsibility for surveillance is held within the provincial health ministry, which has the authority to lead ongoing assessments of SEZ health risks on a regular basis as well as when required (e.g., in cases of an emergence or reemergence of an infectious disease). Surveillance will require access to diverse data; therefore, an MOU is required between the health ministry and other authorities for ease of access to these data. Health surveillance will require the continued collection-and analysis-of leading and lagging health and safety indicators at predetermined intervals. Appendix 1 outlines data collection intervals. 
Figure 7. Different Surveillance Data Required for Effective Management of Community and Worker Health and Safety Risks and Issues

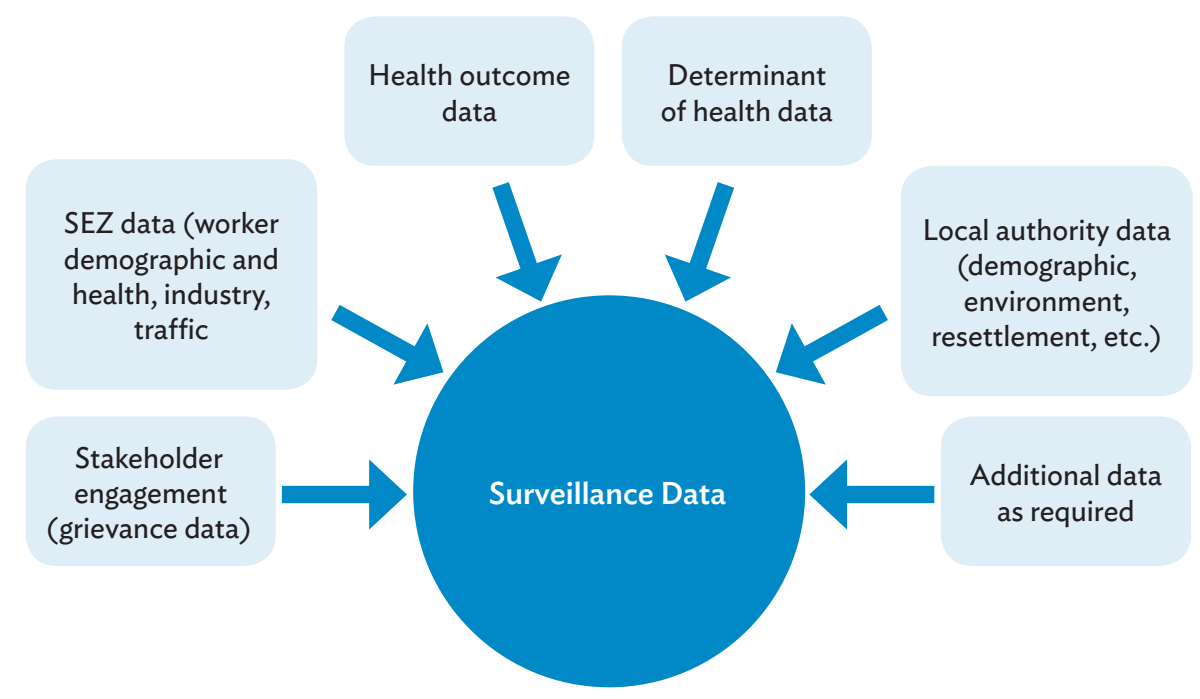

Note: In terms of workers, the data are primarily focused on worker health versus safety. Source: Authors.

\subsection{Transboundary and Cross-Border Surveillance and Response}

Cross-border multidisciplinary health surveillance and response mechanisms are not new concepts and have been required in other jurisdictions to manage risks associated with cross-border surveillance. Since 2015, three provinces including Mukdahan, Thailand; Savannakhet, the Lao PDR; and Quang Tri, Viet Nam have jointly participated in a One Health surveillance system established for 18 health indicators. ${ }^{46}$ Expanded GMS-wide surveillance is recommended and important given the developing cross-border SEZs and potential risks associated with economic corridors. Focus on these areas is crucial not only from a trade, investment, and economic opportunity perspective, but also to protect and enhance the health and well-being of populations on both sides of the borders. There are currently over 50 border provinces associated with SEZs and economic corridors across the GMS representing over 50 million people. These are recommended for expanded health surveillance and response actions.

Finally, surveillance requires an investigation of trends over time. It is also helpful to use a geographic information system (GIS) to map data in order to identify health risk hot spots. It should be anticipated that surveillance processes will improve over time and will require updating and alteration depending on the nature of the SEZ development. Effective surveillance, in addition to the reporting and presentation of data, generally requires a data management system.

\footnotetext{
${ }^{46}$ This surveillance system is available online at http://msq-health.com.
} 


\section{APPENDIX 1 \\ Indicator Suite for Baseline Data and Surveillance}

\begin{tabular}{|c|c|c|}
\hline Indicator & Source of Data & $\begin{array}{l}\text { Surveillance } \\
\text { Interval }\end{array}$ \\
\hline \multicolumn{3}{|l|}{ SEZ Data } \\
\hline No. of industrial tenants & SEZ Management Authority & Monthly \\
\hline $\begin{array}{l}\text { Total workforce population stratified by sex } \\
\text { (male/female/other) }\end{array}$ & $\begin{array}{l}\text { Tenants/SEZ Management } \\
\text { Authority }\end{array}$ & Monthly \\
\hline $\begin{array}{l}\text { Workforce population disaggregated by } \\
\text { residents of SEZ district } \\
\text { - residents of the province } \\
\text { - residents from other areas of the country } \\
\text { - residents of other GMS country } \\
\text { - residents of other non-GMS country }\end{array}$ & $\begin{array}{l}\text { Tenants/SEZ Management } \\
\text { Authority }\end{array}$ & Monthly \\
\hline $\begin{array}{l}\text { Demographic composition of workforce } \\
\text { population disaggregated by age and gender }\end{array}$ & $\begin{array}{l}\text { Tenants/SEZ Management } \\
\text { Authority }\end{array}$ & Monthly \\
\hline Types of industrial tenants & SEZ Management Authority & Monthly \\
\hline $\begin{array}{l}\text { No. of industrial tenants that transport } \\
\text { hazardous materials inside or outside of SEZ }\end{array}$ & SEZ Management Authority & Monthly \\
\hline No. and location of worker accommodations & $\begin{array}{l}\text { Tenants/SEZ Management } \\
\text { Authority }\end{array}$ & Monthly \\
\hline $\begin{array}{l}\text { No. of worker accommodations that pass } \\
\text { health and safety assessment }\end{array}$ & Inspection report & Monthly \\
\hline $\begin{array}{l}\text { No. of tenants that provide health insurance } \\
\text { for their workers }\end{array}$ & $\begin{array}{l}\text { Tenants/SEZ Management } \\
\text { Authority }\end{array}$ & Monthly \\
\hline No. of projects by category type & SEZ Management Authority & Monthly \\
\hline No. of worker accommodations by SEZ tenant & $\begin{array}{l}\text { Tenants/SEZ Management } \\
\text { Authority }\end{array}$ & Monthly \\
\hline $\begin{array}{l}\text { Total population of each worker } \\
\text { accommodation facility by resident type }\end{array}$ & $\begin{array}{l}\text { Tenants/ SEZ Management } \\
\text { Authority }\end{array}$ & Monthly \\
\hline \multicolumn{3}{|l|}{ SEZ Data (Gender-Equity Focused) ${ }^{1}$} \\
\hline $\begin{array}{l}\text { No. of trainings/workshops/seminars on } \\
\text { gender-equity }\end{array}$ & $\begin{array}{l}\text { Tenants/ SEZ Management } \\
\text { Authority }\end{array}$ & Annually \\
\hline $\begin{array}{l}\text { Percentage of human resource staff trained } \\
\text { on gender-sensitive hiring practices, } \\
\text { discrimination, monitoring, and grievance } \\
\text { management }\end{array}$ & $\begin{array}{l}\text { Tenants/SEZ Management } \\
\text { Authority }\end{array}$ & Annually \\
\hline $\begin{array}{l}\text { Percentage of line and floor supervisors } \\
\text { trained on sexual harassment and } \\
\text { discrimination }\end{array}$ & $\begin{array}{l}\text { Tenants/SEZ Management } \\
\text { Authority }\end{array}$ & Annually \\
\hline
\end{tabular}


Appendix Table continued

\begin{tabular}{|c|c|c|}
\hline Indicator & Source of Data & $\begin{array}{c}\text { Surveillance } \\
\text { Interval }\end{array}$ \\
\hline $\begin{array}{l}\text { Percentage of SEZ businesses associated with } \\
\text { an organized labor association }\end{array}$ & $\begin{array}{l}\text { Tenants/SEZ Management } \\
\text { Authority }\end{array}$ & Annually \\
\hline $\begin{array}{l}\text { Percentage of grievances based on gender- } \\
\text { related issues (discrimination, sexual } \\
\text { harassment) }\end{array}$ & $\begin{array}{l}\text { Tenants/SEZ Management } \\
\text { Authority }\end{array}$ & Annually \\
\hline \multicolumn{3}{|c|}{ Retrospective/Lagging Community Health Indicators } \\
\hline $\begin{array}{l}\text { Incidence/prevalence and death rates for } \\
\text { H1N1, H5N1, AFP, SARS, cholera/severe } \\
\text { diarrhea, encephalitis, tetanus, meningitis, } \\
\text { diphtheria, PHEIC }\end{array}$ & Regional health surveillance system & 24 hours \\
\hline $\begin{array}{l}\text { Incidence/prevalence and death rates for } \\
\text { leptospirosis, Chikungunya, dengue fever, } \\
\text { typhoid fever, measles }\end{array}$ & Regional health surveillance system & Weekly \\
\hline $\begin{array}{l}\text { Incidence/prevalence and death rates for } \\
\text { malaria and pneumonia }\end{array}$ & Regional health surveillance system & Monthly \\
\hline $\begin{array}{l}\text { Incidence/prevalence and death rates for } \\
\text { HIV/AIDS, tuberculosis, and syphilis }\end{array}$ & Regional health surveillance system & Quarterly \\
\hline $\begin{array}{l}\text { Incidence/prevalence rates for violence- } \\
\text { related injury }\end{array}$ & Regional health surveillance system & Quarterly \\
\hline $\begin{array}{l}\text { Incidence rates for traffic injuries and } \\
\text { mortalities }\end{array}$ & Regional health surveillance system & Quarterly \\
\hline $\begin{array}{l}\text { No. of health-related grievances filed related } \\
\text { to SEZ development }\end{array}$ & Multisectoral & Quarterly \\
\hline \multicolumn{3}{|c|}{ Retrospective/Lagging Worker Health Indicators } \\
\hline $\begin{array}{l}\text { Incidence/prevalence and death rates for } \\
\text { H1N1, H5N1, AFP, SARS, cholera/severe } \\
\text { diarrhea, encephalitis, tetanus, meningitis, } \\
\text { diphtheria, PHEIC }\end{array}$ & $\begin{array}{l}\text { SEZ health clinic/Regional health } \\
\text { surveillance system }\end{array}$ & 24 hours \\
\hline $\begin{array}{l}\text { Incidence/prevalence and death rates for } \\
\text { leptospirosis, Chikungunya, dengue fever, } \\
\text { typhoid fever, measles }\end{array}$ & $\begin{array}{l}\text { SEZ health clinic/Regional health } \\
\text { surveillance system }\end{array}$ & Weekly \\
\hline $\begin{array}{l}\text { Incidence/prevalence and death rates for } \\
\text { malaria and pneumonia }\end{array}$ & $\begin{array}{l}\text { SEZ health clinic/Regional health } \\
\text { surveillance system }\end{array}$ & Monthly \\
\hline $\begin{array}{l}\text { Incidence/prevalence and death rates for } \\
\text { HIV/AIDS, tuberculosis, and syphilis }\end{array}$ & $\begin{array}{l}\text { SEZ health clinic/Regional health } \\
\text { surveillance system }\end{array}$ & Quarterly \\
\hline $\begin{array}{l}\text { No. of health-related grievances filed related } \\
\text { to SEZ development }\end{array}$ & SEZ Authority & Quarterly \\
\hline \multicolumn{3}{|c|}{ Leading Community Health and Safety Indicators } \\
\hline $\begin{array}{l}\text { Total no. of health promotion activities by } \\
\text { retrospective health data type }\end{array}$ & $\begin{array}{l}\text { Department of preventative } \\
\text { medicine }\end{array}$ & Biannually \\
\hline $\begin{array}{l}\text { Total no. of emergency preparedness and } \\
\text { response drills }\end{array}$ & Provincial hospital records & Biannually \\
\hline $\begin{array}{l}\text { Total no. of table top exercises for incident } \\
\text { command systems }\end{array}$ & Provincial hospital records & Biannually \\
\hline $\begin{array}{l}\text { Percentage of population vaccinated for } \\
\text { monitored health data (where appropriate) }\end{array}$ & Provincial hospital records & Biannually \\
\hline
\end{tabular}


Appendix Table continued

\begin{tabular}{|c|c|c|}
\hline Indicator & Source of Data & $\begin{array}{c}\text { Surveillance } \\
\text { Interval }\end{array}$ \\
\hline $\begin{array}{l}\text { Percentage of survey respondents } \\
\text { with knowledge of communicable and } \\
\text { noncommunicable transmission }\end{array}$ & $\begin{array}{l}\text { Knowledge, Attitudes, and Practice } \\
\text { Survey }\end{array}$ & Annually \\
\hline $\begin{array}{l}\text { Percentage of survey respondents } \\
\text { with knowledge of communicable and } \\
\text { noncommunicable disease prevention and } \\
\text { treatment }\end{array}$ & $\begin{array}{l}\text { Knowledge, Attitudes, and Practice } \\
\text { Survey }\end{array}$ & Annually \\
\hline $\begin{array}{l}\text { Percentage of survey respondents } \\
\text { who correctly identify risk factors for } \\
\text { communicable and noncommunicable diseases }\end{array}$ & $\begin{array}{l}\text { Knowledge, Attitudes, and Practice } \\
\text { Survey }\end{array}$ & Annually \\
\hline $\begin{array}{l}\text { Percentage of survey respondents who } \\
\text { practice correct communicable and } \\
\text { noncommunicable disease prevention and } \\
\text { treatment activities }\end{array}$ & $\begin{array}{l}\text { Knowledge, Attitudes, and Practice } \\
\text { Survey }\end{array}$ & Annually \\
\hline \multicolumn{3}{|l|}{ Leading Worker Health Indicators } \\
\hline Percentage of workers with health insurance & $\begin{array}{l}\text { Tenants/SEZ Management } \\
\text { Authority }\end{array}$ & Monthly \\
\hline $\begin{array}{l}\text { Percentage of workers who have received } \\
\text { health checks }\end{array}$ & $\begin{array}{l}\text { Tenants/SEZ Management } \\
\text { Authority }\end{array}$ & Monthly \\
\hline $\begin{array}{l}\text { Percentage of tenants that have an on- and off- } \\
\text { site code of conduct for the workforce }\end{array}$ & $\begin{array}{l}\text { Tenants/SEZ Management } \\
\text { Authority }\end{array}$ & Quarterly \\
\hline $\begin{array}{l}\text { Percentage of tenants that provide social } \\
\text { induction training outlining health } \\
\text { background of host communities; prevention } \\
\text { measures and where to access health service }\end{array}$ & $\begin{array}{l}\text { Tenants/SEZ Management } \\
\text { Authority }\end{array}$ & Quarterly \\
\hline $\begin{array}{l}\text { No. of workers targeted for education and } \\
\text { awareness training for communicable and } \\
\text { noncommunicable disease transmission, } \\
\text { prevention and treatment }\end{array}$ & $\begin{array}{l}\text { Tenants/SEZ Management } \\
\text { Authority }\end{array}$ & Quarterly \\
\hline $\begin{array}{l}\text { No. of worker accommodations that pass } \\
\text { health and safety assessment }\end{array}$ & Public health ministry & Monthly \\
\hline $\begin{array}{l}\text { Percentage of workers with knowledge } \\
\text { of communicable and noncommunicable } \\
\text { transmission }\end{array}$ & $\begin{array}{l}\text { Knowledge, Attitudes, and Practice } \\
\text { Survey }\end{array}$ & Annually \\
\hline $\begin{array}{l}\text { Percentage of workers with knowledge of } \\
\text { communicable and noncommunicable disease } \\
\text { prevention and treatment }\end{array}$ & $\begin{array}{l}\text { Knowledge, Attitudes, and Practice } \\
\text { Survey }\end{array}$ & Annually \\
\hline $\begin{array}{l}\text { Percentage of workers who correctly } \\
\text { identify risk factors for communicable and } \\
\text { noncommunicable diseases }\end{array}$ & $\begin{array}{l}\text { Knowledge, Attitudes, and Practice } \\
\text { Survey }\end{array}$ & Annually \\
\hline $\begin{array}{l}\text { Percentage of workers who practice correct } \\
\text { communicable and noncommunicable disease } \\
\text { prevention and treatment activities }\end{array}$ & $\begin{array}{l}\text { Knowledge, Attitudes, and Practice } \\
\text { Survey }\end{array}$ & Annually \\
\hline \multicolumn{3}{|l|}{ Resettlement-Related Health Indicators } \\
\hline $\begin{array}{l}\text { Population of resettled population stratified by } \\
\text { age, sex, and previous working status }\end{array}$ & Government data & $\begin{array}{l}\text { When } \\
\text { required }\end{array}$ \\
\hline
\end{tabular}


Appendix Table continued

\begin{tabular}{|c|c|c|}
\hline Indicator & Source of Data & $\begin{array}{l}\text { Surveillance } \\
\text { Interval }\end{array}$ \\
\hline $\begin{array}{l}\text { Percentage of resettled houses with complete } \\
\text { infrastructure }\end{array}$ & Household Survey & $\begin{array}{l}\text { Annually for } \\
\text { first } 3 \text { years }\end{array}$ \\
\hline $\begin{array}{l}\text { Percentage of households that have secure } \\
\text { land tenure }\end{array}$ & Household Survey & $\begin{array}{l}\text { Annually for } \\
\text { first } 3 \text { years }\end{array}$ \\
\hline $\begin{array}{l}\text { Percentage of households that have access to } \\
\text { primary health care services locally }\end{array}$ & Household Survey & $\begin{array}{l}\text { Annually for } \\
\text { first } 3 \text { years }\end{array}$ \\
\hline $\begin{array}{l}\text { Percentage of households participating in non- } \\
\text { agricultural/subsistence economy }\end{array}$ & Household Survey & $\begin{array}{l}\text { Annually for } \\
\text { first } 3 \text { years }\end{array}$ \\
\hline $\begin{array}{l}\text { Percentage of resettled households with access } \\
\text { to basic needs (clean water, sanitation, and } \\
\text { waste management) }\end{array}$ & Household Survey & $\begin{array}{l}\text { Annually for } \\
\text { first } 3 \text { years }\end{array}$ \\
\hline $\begin{array}{l}\text { Percentage of population of working age are } \\
\text { employed }\end{array}$ & Household Survey & $\begin{array}{l}\text { Annually for } \\
\text { first } 3 \text { years }\end{array}$ \\
\hline $\begin{array}{l}\text { Percentage of population who have food } \\
\text { security }\end{array}$ & Household Survey & $\begin{array}{l}\text { Annually for } \\
\text { first } 3 \text { years }\end{array}$ \\
\hline $\begin{array}{l}\text { Percentage of population who may be } \\
\text { experiencing stress-related mental health } \\
\text { issues as a result of relocation (anxiety and } \\
\text { depression) }\end{array}$ & Household Survey & $\begin{array}{l}\text { Annually for } \\
\text { first } 3 \text { years }\end{array}$ \\
\hline \multicolumn{3}{|c|}{ Environmental Health Indicators* } \\
\hline \multicolumn{3}{|c|}{$\begin{array}{l}\text { These should be based upon review of the industrial tenants in comparison with the World Bank } \\
\text { Environmental, Health, and Safety Industry Sector Guidelines. http://www.ifc.org/wps/wcm/ } \\
\text { connect/topics_ext_content/ifc_external_corporate_site/sustainability-at-ifc/policies-standards/ } \\
\text { ehs-guidelines }\end{array}$} \\
\hline
\end{tabular}

AFP = acute flaccid paralysis, GMS = Greater Mekong Subregion, PHEIC = public health emergency of international concern, SARS = severe acute respiratory syndrome, SEZ = special economic zone

a International Bank for Reconstruction and Development/World Bank. 2011. Fostering Women's Economic Empowerment through Special Economic Zones: Comparative Analysis of Eight Countries and Implications for Governments, Zone Authorities and Businesses. https://herproject.org/downloads/sez-and-womenglobal.pdf (retrieved on 12 December 2017). 


\section{APPENDIX 2 \\ Additional Data Collection Tools}

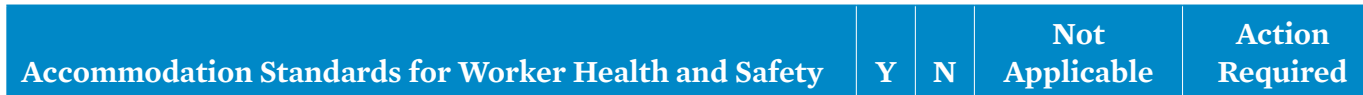

\section{General Living Facilities}

Location of accommodation is safe from flooding and landslips

Free and safe transport is provided from accommodation to worksite

Accommodations are clean and kept in good condition

Accommodation site is adequately drained

Heating, air conditioning, ventilation, and lighting

Accommodation facility is properly ventilated

Adequate lights are provided, including emergency lighting

A window area covering approximately $5 \%-10 \%$ of the total wall space is present in all rooms

Electrical fittings are installed in the workers accommodation facility and are inspected every 6 months

All electrical circuits and equipment have been earthed and fitted with earth protective devices to reduce the risk of electrocution

\section{Wastewater and Solid Waste}

Wastewater, sewage, food, and other waste products are properly disposed in compliance with national standards

Local contractor has been hired to empty septic tanks on a routine basis

Subcontractor is monitoring environmental surroundings of the camp

Garbage containers are provided and routinely emptied

A pest extermination point person has been assigned

Accommodation has a pest control management procedure

A waste inventory has been developed

Waste is separated and labeled appropriately

Rooms/Dormitories

Rooms/dormitories are routinely cleaned and kept in good condition

Floor material of rooms/dormitories are made of material that is easily cleaned

Sanitary facilities are located in reasonable proximity to rooms/dormitories 
Appendix Table continued

\begin{tabular}{|l|l|l|c|c} 
Accommodation Standards for Worker Health and Safety & Y & N & $\begin{array}{c}\text { Not } \\
\text { Applicable }\end{array}$ & $\begin{array}{c}\text { Action } \\
\text { Required }\end{array}$
\end{tabular}

Resident workers are provided enough space (10-12.5 cubic meters or floor area of 45.5 square meters and a minimum ceiling height of 2.1 meters)

The number of resident workers who share accommodation space is minimized (no more than eight workers per room)

Doors and windows have locks

Doors and windows have mosquito screens

When accommodation space is shared, partitions and curtains are available

There are separate living facilities for male and female workers

\section{Bedding and Storage}

Each resident worker has his/her individual bed

Each resident worker receives a clean pillow, mattress, blanket, and bedding linen

A minimum distance of 1 meter exists between each bed

Triple bunk beds are not used

Resident workers have space to store personal belongings (at least one personal cupboard per worker).

Bathrooms, showers, and sanitary facilities

There is an adequate number of toilets ( 1 per 15 persons per gender), urinals ( 1 per 15 persons), handwashing basin ( 1 per 6-15 persons), and showers ( 1 per 20 persons) are available

Toilet and sanitary facilities are convenient and easily accessible

Showers are built using anti-slip flooring that is easily washable

Shower facilities are provided with an adequate amount of hot and cold water

Laundry Facilities

Facilities to wash and dry laundry are provided

These facilities are routinely cleaned

Laundry facilities are built with material that is easy to clean

Canteen and Cooking Facilities

Canteen and cooking facilities are routinely cleaned and sanitized

No cooking is permitted in sleeping areas

Food preparation area is adequately ventilated and equipped

Kitchen floors, walls, ceilings, and counters are nonabsorbent, nontoxic, durable, and easy to clean

Cleaning and disinfecting facilities are provided

Storage for cooking utensils is provided

continued on next page 
Appendix Table continued

\begin{tabular}{|c|c|c|c|c|}
\hline Accommodation Standards for Worker Health and Safety & $\mathbf{Y}$ & $\mathbf{N}$ & $\begin{array}{l}\text { Not } \\
\text { Applicable }\end{array}$ & $\begin{array}{l}\text { Action } \\
\text { Required }\end{array}$ \\
\hline $\begin{array}{l}\text { Food waste and other garbage are disposed in sealable } \\
\text { containers and are routinely removed from kitchen area to } \\
\text { prevent accumulation }\end{array}$ & & & & \\
\hline Food safety and nutrition & & & & \\
\hline 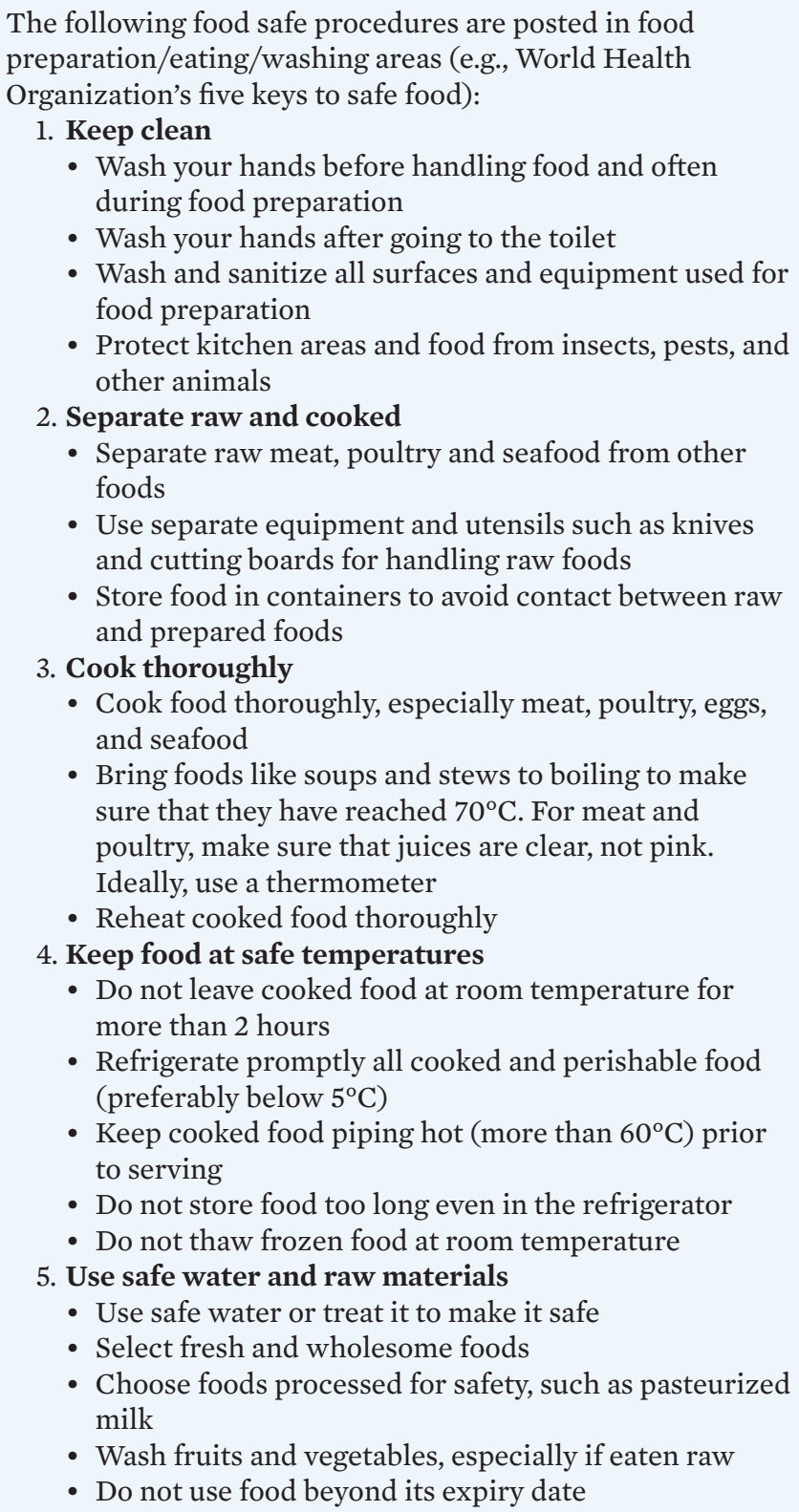 & & & & \\
\hline \multicolumn{5}{|l|}{ Medical Facilities } \\
\hline \multicolumn{5}{|l|}{$\begin{array}{l}\text { There is a first aid room that is staffed by health practitioners } \\
7 \text { days a week, } 24 \text { hours a day }\end{array}$} \\
\hline \multicolumn{5}{|l|}{ Workers have received first aid training } \\
\hline Workers have received a health check & & & & \\
\hline
\end{tabular}


Appendix Table continued

\begin{tabular}{|c|c|c|c|c|}
\hline Accommodation Standards for Worker Health and Safety & $\mathbf{Y}$ & $\mathbf{N}$ & $\begin{array}{l}\text { Not } \\
\text { Applicable }\end{array}$ & $\begin{array}{l}\text { Action } \\
\text { Required }\end{array}$ \\
\hline \multicolumn{5}{|l|}{$\begin{array}{l}\text { Accommodation has policies on HIV and communicable } \\
\text { diseases, drugs, and alcohol }\end{array}$} \\
\hline \multicolumn{5}{|l|}{ Worker Conduct } \\
\hline \multicolumn{5}{|l|}{$\begin{array}{l}\text { Incidents and conduct issues involving workers are being } \\
\text { recorded and investigated }\end{array}$} \\
\hline \multicolumn{5}{|l|}{$\begin{array}{l}\text { Possession of illegal drugs and alcohol is strictly enforced } \\
\text { and personnel may be subject to immediate dismissal }\end{array}$} \\
\hline \multicolumn{5}{|l|}{$\begin{array}{l}\text { All workers have been given an induction to the SEZ area, } \\
\text { expected codes of conduct, and the special economic zone's } \\
\text { grievance mechanism }\end{array}$} \\
\hline \multicolumn{5}{|l|}{$\begin{array}{l}\text { Visitor entrance and exit policies are developed and } \\
\text { implemented }\end{array}$} \\
\hline \multicolumn{5}{|l|}{ Disciplinary procedures are developed and implemented } \\
\hline \multicolumn{5}{|l|}{ Security } \\
\hline \multicolumn{5}{|l|}{ Security controls are present at the entrance of the camp } \\
\hline \multicolumn{5}{|l|}{$\begin{array}{l}\text { A security policy has been developed that take takes } \\
\text { appropriate measures to protect accommodation staff and } \\
\text { workers against theft and attack }\end{array}$} \\
\hline \multicolumn{5}{|l|}{ Fire } \\
\hline \multicolumn{5}{|l|}{ All buildings have a fire system installed } \\
\hline \multicolumn{5}{|l|}{$\begin{array}{l}\text { All accommodations should provide adequate means for } \\
\text { individuals who are asleep to escape in case of a fire }\end{array}$} \\
\hline \multicolumn{5}{|l|}{$\begin{array}{l}\text { Fire extinguishers are present next to all exit doors and } \\
\text { adjacent to high-risk areas (e.g., cooking stove) }\end{array}$} \\
\hline $\begin{array}{l}\text { Fire evacuation drills and exercises are performed regularly } \\
\text { in conjunction with testing fire equipment; all drills and } \\
\text { exercises are recorded }\end{array}$ & & & & \\
\hline
\end{tabular}

Source: International Finance Corporation and European Bank for Reconstruction and Development. 2009. Worker Accommodation Process and Standards: A Guidance Note by IFC and EBRD. Washington, DC: World Bank. http://www.ebrd.com/downloads/about/history/workers.pdf (retrieved on 16 November 2017). 


\section{APPENDIX 3 \\ Grievance Management Resources}

The effective management of grievances requires a systematic process to receive, investigate, and respond to questions and complaints. Grievance management is a normal part of business functions, and includes the development and management of special economic zones.

Over the last decade, considerable effort has been placed on developing guidance material on effective grievance management. One of the most widely recognized robust set of tools and guidance on grievance management and mechanisms has been developed by the petrochemical sector. This toolbox is easily adaptable to any setting including a special economic zones and is available online:

International Petroleum Industry Environmental Conservation Association (IPIECA). 2014. Community Grievance Mechanism. http://www.ipieca.org/news/ipieca-launchescommunity-grievance-mechanism-toolbox/. 


\section{APPENDIX 4 Gender Equality Standards for Special Economic Zone Authorities and Businesses}

\begin{tabular}{|c|c|c|c|c|}
\hline Questions on Standards & $\mathbf{Y}$ & $\mathbf{N}$ & $\begin{array}{l}\text { Not } \\
\text { Applicable }\end{array}$ & $\begin{array}{l}\text { Action } \\
\text { Required }\end{array}$ \\
\hline $\begin{array}{l}\text { Does the SEZ and associated businesses have a gender } \\
\text { policy? }\end{array}$ & & & & \\
\hline $\begin{array}{l}\text { Is the SEZ linked formally with women's organizations to } \\
\text { provide consultation and advice on policy development to } \\
\text { improve gender equality in the zone? }\end{array}$ & & & & \\
\hline $\begin{array}{l}\text { Has the SEZ authority along with managers of SEZ } \\
\text { businesses received training to recognize, identify, and } \\
\text { manage gender issues appropriately and sensitively? }\end{array}$ & & & & \\
\hline $\begin{array}{l}\text { Is workforce data at the SEZ level disaggregated based on } \\
\text { gender? }\end{array}$ & & & & \\
\hline $\begin{array}{l}\text { Does the SEZ and associated businesses have a grievance } \\
\text { mechanism that is used and trusted by female workers? }\end{array}$ & & & & \\
\hline $\begin{array}{l}\text { Are SEZ businesses aware of national laws pertaining to } \\
\text { female workers' labor rights and basic human rights and are } \\
\text { conditions monitored for ensuring these rights are met? }\end{array}$ & & & & \\
\hline $\begin{array}{l}\text { Does the SEZ and associated businesses actively promote } \\
\text { and support female workers' health and well-being? }\end{array}$ & & & & \\
\hline
\end{tabular}

SEZ = special economic zone.

Source: International Bank for Reconstruction and Development/World Bank. 2011. Fostering Women's Economic Empowerment through Special Economic Zones: Comparative Analysis of Eight Countries and Implications for Governments, Zone Authorities and Businesses. https://herproject.org/downloads/sez-andwomen-global.pdf (retrieved on 12 December 2017). 


\section{APPENDIX 5 \\ Health Risk Assessment Tools}

For each health risk identified during the health impact assessment, determine the level of risk based on the likelihood of the event occurring and the associated consequence. There are four possible risk ratings. Moderate, major, and catastrophic risks require review, attention, management, and surveillance. Low risks still require surveillance and ongoing management to ensure consistency.

\begin{tabular}{|c|c|c|c|c|c|c|}
\hline \multicolumn{7}{|c|}{ Health Risk Assessment Matrix } \\
\hline & Consequence & 1 & 2 & 3 & 4 & 5 \\
\hline Likelihood & Descriptor & $\begin{array}{l}\text { Minor injury or } \\
\text { illness; First Aid }\end{array}$ & $\begin{array}{c}\text { Requires } \\
\text { medical } \\
\text { treatment; } \\
\text { temporary } \\
\text { impact to } \\
\text { livelihood }<7 \\
\text { days }\end{array}$ & $\begin{array}{c}\text { Requires } \\
\text { medical } \\
\text { treatment; } \\
\text { longer term } \\
\text { impact to } \\
\text { livelihood > } 7 \\
\text { days }\end{array}$ & $\begin{array}{l}\text { Prolonged } \\
\text { major illness/ } \\
\text { injury; } \\
\text { permanent } \\
\text { impact on } \\
\text { livelihood }\end{array}$ & $\begin{array}{c}\text { Multiple cases, } \\
\text { death or severe } \\
\text { injury/illness; } \\
\text { permanent } \\
\text { impact on } \\
\text { livelihood }\end{array}$ \\
\hline 1 & $\begin{array}{c}\text { Rare-only } \\
\text { will occur in } \\
\text { exceptional } \\
\text { cases; once } \\
\text { every decade }\end{array}$ & LOW & LOW & MODERATE & MODERATE & MODERATE \\
\hline 2 & $\begin{array}{l}\text { Unlikely-may } \\
\text { occur between } \\
5 \text { and } 10 \text { years- }\end{array}$ & LOW & LOW & MODERATE & MAJOR & MAJOR \\
\hline 3 & $\begin{array}{c}\text { Possible-likely } \\
\text { to happen this } \\
\text { year }\end{array}$ & MODERATE & MODERATE & MAJOR & CATASTROPIC & CATASTROPIC \\
\hline 4 & $\begin{array}{l}\text { Likely to } \\
\text { happen } \\
\text { monthly }\end{array}$ & MODERATE & MAJOR & CATASTROPIC & CATASTROPIC & CATASTROPIC \\
\hline 5 & $\begin{array}{l}\text { Expected to } \\
\text { occur, has } \\
\text { occurred, and } \\
\text { has impact }\end{array}$ & MODERATE & MAJOR & CATASTROPIC & CATASTROPIC & CATASTROPIC \\
\hline
\end{tabular}


The rationale for the ranking and prioritizing of health risks, in addition to the identification of management action items, can be supported by the following table. An example of addressing traffic-related injury and death is provided.

\begin{tabular}{|c|c|c|c|c|c|c|c|}
\hline \multicolumn{8}{|c|}{ Prioritizing and Managing Health Risks } \\
\hline $\begin{array}{l}\text { Health } \\
\text { Issue }\end{array}$ & $\begin{array}{l}\text { Description and } \\
\text { Supporting Data }\end{array}$ & $\begin{array}{c}\text { Health } \\
\text { Consequence }\end{array}$ & Likelihood & Risk & $\begin{array}{c}\text { Risk } \\
\text { Management } \\
\text { in Place }\end{array}$ & $\begin{array}{l}\text { Management } \\
\text { Actions }\end{array}$ & Responsibility \\
\hline \multirow[t]{3}{*}{$\begin{array}{l}\text { Traffic } \\
\text { Injury } \\
\text { and } \\
\text { Death }\end{array}$} & \multirow{3}{*}{$\begin{array}{l}\text { - Poor road conditions } \\
\text { and driving discipline } \\
\text { - Roads shared by } \\
\text { multiple users in a } \\
\text { disorganized fashion } \\
\text { - Lack of traffic safety } \\
\text { infrastructure } \\
\text { including lights, stop } \\
\text { signs, and traffic safety } \\
\text { personnel (in case of } \\
\text { road construction or } \\
\text { emergencies) } \\
\text { - Deaths and severe } \\
\text { injury happen weekly }\end{array}$} & \multirow[t]{3}{*}{5} & \multirow[t]{3}{*}{5} & \multirow[t]{3}{*}{ Catastrophic } & \multirow[t]{3}{*}{ No } & $\begin{array}{l}\text { Improvement } \\
\text { of traffic } \\
\text { infrastructure }\end{array}$ & $\begin{array}{l}\text { Transportation } \\
\text { ministry }\end{array}$ \\
\hline & & & & & & $\begin{array}{l}\text { Identification } \\
\text { of traffic } \\
\text { injury and } \\
\text { mortality hot } \\
\text { spots }\end{array}$ & $\begin{array}{l}\text { Local police } \\
\text { and public } \\
\text { health ministry }\end{array}$ \\
\hline & & & & & & $\begin{array}{l}\text { Safe driving } \\
\text { campaigns; } \\
\text { behaviour } \\
\text { change }\end{array}$ & $\begin{array}{l}\text { SEZ Authority, } \\
\text { local police, } \\
\text { public health } \\
\text { ministry }\end{array}$ \\
\hline
\end{tabular}




\section{A Health Impact Assessment Framework for Special Economic Zones in the Greater Mekong Subregion}

Across the Greater Mekong Subregion (GMS), there are over 500 special economic zones (SEZs) and industrial zones located near GMS economic corridors and covering over 50 million people. This proposed health impact assessment (HIA) framework recognizes these SEZs and economic corridors as economic engines of the subregion and aims to maximize benefits for all. The framework aims to provide enhanced guidance for identifying, mitigating, and managing health risks and impacts of unprecedented industrial and economic development in these SEZs, and seeks to address transboundary health issues associated with mobile and migrant worker populations. It proposes HIA as an effective SEZ management support tool to achieve optimum benefits for businesses and associated communities alike.

\section{About the Asian Development Bank}

ADB's vision is an Asia and Pacific region free of poverty. Its mission is to help its developing member countries reduce poverty and improve the quality of life of their people. Despite the region's many successes, it remains home to a large share of the world's poor. ADB is committed to reducing poverty through inclusive economic growth, environmentally sustainable growth, and regional integration.

Based in Manila, ADB is owned by 67 members, including 48 from the region. Its main instruments for helping its developing member countries are policy dialogue, loans, equity investments, guarantees, grants, and technical assistance. 